The Effects of Ownership Forms and Concentration on Firm Performance after Large-Scale Privatization

\author{
By: Evzen Kocenda and Jan Svejnar
}

William Davidson Working Paper Number 471

May 2002 


\title{
The Effects of Ownership Forms and Concentration on Firm Performance after Large- Scale Privatization
}

\author{
Evzen Kocenda* \\ and \\ Jan Svejnar**
}

May 2002

\begin{abstract}
We analyze the effect of ownership on post-privatization performance in a virtually complete population of medium and large firms privatized in a model large-scale privatization economy (Czech Republic). We reject the hypothesis that domestic or foreign private ownership, in either moderate or high ownership concentrations, leads to increased sales. However, private domestic and foreign majority and significant minority owners, as well as dispersed owners, increase profitability relative to state-owned firms. Firms with dispersed ownership register higher positive effect on profit than firms with more concentrated ownership, thus giving support to theories stressing managerial autonomy and initiative. Foreign owners with high as well as moderate concentrations of ownership uniformly reduce financial leverage, as do majority domestic owners. Domestic banks and portfolio companies as single largest owners (SLO) are incapable of carrying out major restructuring. Foreign industrial company SLOs carry out strategic restructuring in production and financing without deviating from the state ownership benchmark in terms of the labor cost. The effect of SLO does not vary with the SLO's concentration of ownership. Overall, private ownership tends to be associated with superior performance in terms of some indicators but not others, and dispersed ownership results in better or equal performance than more concentrated forms of ownership.
\end{abstract}

Keywords: ownership, performance, privatization, panel data, industrial organization JEL Classification: C33, D20, G32, G34, L20

* CERGE-EI, Prague and The William Davidson Institute at the University of Michigan Business School

** The William Davidson Institute at the University of Michigan Business School and Department of Economics, University of Michigan; CERGE-EI, Prague

We would like to thank Juraj Valachy for valuable computational assistance. We are indebted for valuable comments to Nandini Gupta, Jan Hanousek, Gábor Kezdi, Jan Kmenta, Lubomír Lízal, and Klara Sabirianova. While preparing this paper, Svejnar benefited from ACE Grant No. P-98-1008-R and NSF Grant No. SBR-951-2001.

This material is based upon work supported by the National Science Foundation under Grant No. 0111783. Any opinions, findings, and conclusions or recommendations expressed in this material are those of the author(s) and do not necessarily reflect the views of the National Science Foundation. 


\section{William Davidson Institute Working Paper 471}

\section{Introduction}

One of the fundamental and empirically most controversial economic questions is whether private firms perform better than state-owned enterprises (SOEs) and whether privatization improves firm performance. There is now a large literature on the subject and the issue has gained currency as large-scale privatizations have taken place in many countries of the former Soviet bloc and Yugoslavia, and as countries such as China and India consider similar, large transformations.

Interestingly, while privatization is based on the premise that it will improve corporate performance and help countries grow, the effect has been surprisingly hard to identify. At the macro level, one observes that some of the fastest growing transition economies (e.g., China, Poland and Slovenia) have been among the slowest to privatize, while some of the fastest privatizers (e.g., Russia, Ukraine and the Czech Republic) experienced a decline or slow growth after privatization in the 1990s. In a cross-country aggregate study, Sachs, Zinnes and Eilat (2000) find that privatization does not by itself increase GDP growth, but they suggest that a positive effect is present when privatization is accompanied by in-depth institutional reforms. Careful micro-econometric studies date back to Caves and Christensen's (1980) classic study that found the private and state-owned Canadian railways performing equally efficiently in a head-on competition. Recent surveys of privatization studies based on micro data come up with assessments that range from finding a large variation of outcomes but no systematically significant effect of privatization on performance (Bevan, Estrin and Schaffer, 1999), to cautiously concluding that privatization around the world improves firm performance (Megginson and Netter, 2001), to being fairly confident that privatization tends to improve performance (Shirley and Walsh, 2000, and Djankov and Murrell, 2000).

In part, the variation in results is brought about by the fact that different studies have access to different, and often very limited, data on firm ownership. For these reasons, most 


\section{William Davidson Institute Working Paper 471}

studies treat ownership as a relatively simple categorical concept (e.g., private v. state or state v. foreign, domestic private outsider v. domestic private insider), and they are unable to distinguish the exact extent of ownership by individual owners or even relatively homogeneous groups of owners. ${ }^{1}$ As we discuss below, the inability to distinguish the extent of different forms of ownership also prevents many studies from providing evidence on a lively theoretical debate about the desirability of concentrated v. dispersed ownership on corporate performance. ${ }^{2}$

Equally important, the diversity of findings is generated by three types of analytical problems that may be expected in early studies, especially those in the context of the rapidly changing transition economies. First, these studies often mix data from different accounting systems and many are not able to distinguish accurately differences in ownership as privatization was still ongoing during the period under study (see Filer and Hanousek, 2002). Second, the early studies use small and unrepresentative samples of firms and they rely on a short period of time with observations concentrated immediately before and/or after privatization. ${ }^{3}$ They may hence produce biased estimates and they capture only the short-term effects of privatization, namely those associated with defensive (reactive) restructuring of firms. ${ }^{4}$ However, as we discuss in Section 2, the early ownership patterns were often unstable, frequent ownership changes were hard to detect, and temporary owners did not necessarily engage in restructuring. The estimates of the immediate post-privatization effects may hence not reflect the true medium and long-term effects of a switch from state to a relatively stable frm of private or mixed

\footnotetext{
${ }^{1}$ See for example Pohl, Anderson, Claessens, and Djankov (1997), Smith, Cin, and Vodopivec (1997), Claessens and Djankov (1999), and Frydman, Hessel, and Rapaczynski (2000).

${ }_{3}^{2}$ An important recent exception is Grossfeld and Tressel (2001).

${ }^{3}$ For example, Frydman, Gray, Hessel and Rapaczynski (1999) use a 1990-93 sample of about 200 firms pooled from the Czech Republic, Hungary and Poland; Barberis, Boycko, Shleifer, and Tsukanova (1996) use a sample of 260-340 Russian shops during the 1992-93 period; Bilsen and Konings (1998) use survey data for 1990-94 on about 260 firms divided among Bulgaria, Romania, and Hungary; Grosfeld and Nivet (1997) use a sample of 173 of the largest 500 companies in Poland during the 1988-1994 period; and Claessens and Djankov (1999) use data on approximately 700 manufacturing firms from the Czech Republic during 1993-97.

${ }^{4}$ See Grosfeld and Roland (1997) and Aghion and Carlin (1996) for discussions of the defensive and reactive restructuring.
} 


\section{William Davidson Institute Working Paper 471}

ownership. Third, a selection bias may be a serious problem in that many studies estimate the performance effect of privatization by comparing the post-privatization performance of privatized firms to the performance of the remaining state-owned firms. Yet, Gupta, Ham and Svejnar's (2000) econometric evidence indicates that better performing firms tend to be privatized first. Since many studies are unable to control adequately for selectivity, they may erroneously attribute the inherently superior performance of the privatized firms to privatization.

In this paper, we advance the literature by estimating the performance effects of key ownership patterns that we construct from detailed information on the extent of firm ownership by various owners. In particular, we exploit the fact that, unlike other authors, we are able to identify individual firms and obtain detailed information about their ownership and key indicators of performance. We are hence able to estimate the effects of different ownership forms and degrees of ownership concentration that are deemed important by theorists, policy makers, businessmen, and analysts, but the effects of which have not been examined fully in existing studies.

Moreover, we advance the literature by systematically striving to overcome the three types of above-mentioned problems found in existing studies. In particular, we (a) use panel data on a virtually complete population of medium and large firms that were privatized in a model large-scale privatization economy (Czech Republic) and that constitute the bulk of the country's economic activity, ${ }^{5}$ (b) cover a four-year period after privatization, when accounting rules conforming to the international (IAP) standard were already enforced, (c) control for selectivity,

\footnotetext{
5 The Central European economies have served as models for other transition countries in that early on they carried out important reforms and policy makers from other countries and international institutions such as the World Bank and the International Monetary Fund have used them as examples to follow. In this context, the Czech Republic has served as the example of rapid, large scale privatization, while Hungary has been the example of piece-meal privatization of individual firms.
} 


\section{William Davidson Institute Working Paper 471}

and (d) capture the effects after the large-scale privatization and immediate post-large scale privatization changes of ownership took place. ${ }^{6}$

In addition, the fact that we use data from an economy that started almost completely state owned and within a short time span underwent large-scale privatization means that we are analyzing a population of firms that experienced one of the greatest changes in ownership recorded throughout the world. Unlike studies of partial privatization, we hence benefit from large variation in the variables whose effect we analyze.

Finally, by carrying out a detailed study on one model economy, we are able to take into account specific legal and institutional features that relate to ownership and control, and avoid the problem of controlling adequately for complex cross-country differences in the institutional and legal frameworks that plague comparative studies with limited number of country-specific observations. $^{7}$

The structure of the paper is as follows. In Section 2 we provide information on the privatization process that generates our data, while in Section 3 we discuss the relevant features of the legal system and the hypothesized implications of different types of ownership on firm performance. In Section 4 we describe the data and basic statistics and in Section 5 we outline our empirical strategy. We present our empirical estimates in Section 6 and we draw conclusions in Section 7.

\footnotetext{
6 The present paper belongs to a second generation of empirical studies that are being carried out to analyze corporate performance in the post-privatization period and employ large samples or populations of firm-level data from specific types of privatization in a given country. These studies are being able to avoid some of the aforementioned problems and take into account specific institutional settings. Thus, Borenstein (2001) for instance examines the post-privatization restructuring of former SOE, including examples from the Czech Republic, Hungary and Poland. Angelucci, Estrin, Konings and Zólkiewski (2001) use a large representative panel of manufacturing firms covering the years 1997-98 for Bulgaria and Romania, and 1994 and 1998 for Poland. Carlin, Fries, Schaffer and Seabright (2001) use an EBRD survey of 3,300 firms in 25 transition countries to identify the factors that influence restructuring by firms and their subsequent performance as measured by growth in sales and in sales per employee over a 1996-1998 period. Lizal and Svejnar (2002) use a 1992-98 panel data on the population of medium and large Czech industrial firms to examine investment behavior and the extent of credit rationing and soft budget constraints by ownership and corporate form of firms.

${ }^{7}$ Frydman et al's. (1999) study for instance uses pooled cross-country regressions to derive its key findings.
} 


\section{William Davidson Institute Working Paper 471}

\section{Privatization in the Czech Republic}

The privatization program in the Czech Republic was carried out in the first half of the 1990s under three different schemes: restitution, small-scale privatization and large-scale privatization. The first two schemes started in 1990 and were most important during the early years of the transition. Large-scale privatization, by far the most important scheme, began in 1991 and was completed in early $1995 .^{8}$ The privatization program allowed various privatization techniques. Small firms were usually auctioned or sold in tenders. Many medium businesses were sold in tenders or to pre-determined buyers in direct sales. Most large and many medium firms were transformed into joint stock companies and their shares were distributed within voucher privatization (almost one-half of the total number of all shares of all joint stock companies was privatized in the voucher scheme), sold in public auctions or to strategic partners, or transferred to municipalities.

The voucher scheme was part of the large-scale privatization process and it attracted considerable interest and publicity. ${ }^{9}$ Two waves of voucher privatization took place in 1992-93 and 1993-94, respectively. The early post-privatization ownership structure emerged as shares from the second wave were distributed in early 1995. Rapid reallocation of shares across new owners took place in 1995-96 during the so-called "third wave" of privatization as new owners, including the investment privatization funds (IPFs), reshaped their initial post-privatization portfolios of acquired companies. Depending on the investor, the swapping of shares in 1995-96 was aimed at (a) optimal portfolio diversification, (b) obtaining concentrated ownership in

\footnotetext{
8 The privatization process has been extensively described and analyzed. See e.g., Svejnar and Singer (1994), Kotrba (1995), Coffee (1996), and Kocenda (1999).

${ }^{9}$ The voucher scheme is sometimes erroneously referred to as the large-scale privatization program.
} 
specific firms and industries and (c) achieving conformity with legal requirements aimed at preventing excessive stakes being held by privatization funds. ${ }^{10}$

The 1995-96 ownership changes were massive, spontaneous and quite unregulated. Investors, especially the IPFs, engaged in direct swaps of large blocs of shares and off-market share trading was common. More stable and, from the standpoint of firm performance, more meaningful patterns of ownership emerged in 1996. We analyze the performance effects of various patterns of ownership and their changes after the dust of large-scale privatization and early post-privatization ownership swaps settled.

\section{Forms of Ownership and Hypothesized Effects on Performance}

\section{Concentrated or Dispersed Ownership?}

The link between firm performance and ownership is often viewed as going through the interaction and power distribution between the owners and managers of firms. In this context, the issue that has received major renewed attention, without resulting in a consensus, is whether concentrated or dispersed ownership is more conducive to good corporate governance and performance. The literature that focuses on the agency problem arising from the separation of ownership and control usually argues for the desirability of concentrated ownership since it results in better monitoring of managers, maximization of shareholder value and availability of external finance for the firms (e.g., Shleifer and Vishny, 1997). On the other hand, models that stress the importance of managerial initiative and incentives to acquire information (e.g., in situations of high uncertainty) conclude that concentrated ownership may be deleterious to firm

\footnotetext{
${ }^{10}$ The regulation of IPFs evolved gradually through Decree no. 383/1991, its Amendment No. 62/1992, and Act No. 248/1992. The most important clauses restricted each privatization fund from investing more than $10 \%$ of points acquired in the voucher scheme in a single company and obtaining in exchange more than $20 \%$ of shares in any company. Privatization funds established by a single founder were allowed to accumulate up to $40 \%$ shares in a given company but this cap was later reduced to 20\%. Many privatization funds circumvented the cap through mergers. The Act also prohibited IPFs founded by financial institutions from purchasing shares of other financial institutions to prevent excessive concentration of financial capital (see Kotrba and Svejnar, 1994).
} 


\section{William Davidson Institute Working Paper 471}

performance (e.g., Aghion and Tirole, 1997). Dispersed ownership also results in greater liquidity of the company's stock, which is viewed by some as improving the information value of the stock market and therefore enhancing the performance of firms (e.g., Holmstrom and Tirole, 1983). Ownership dispersion may hence be optimal, provided it can give rise to controlling stakes when managerial decisions need to be blocked and/or restructuring needs to be carried out (Bolton and von Thadden, 1998).

Since we use data from firms that were listed on the Prague Stock Exchange and since we are able to identify all owners with ownership stakes of 10 percent or more, we can classify all firms into categories that allow us to test the validity of the competing predictions from the above theories. In particular, the Czech law provides important rights of ownership and control to owners with majority ownership (more than 50 percent of shares), blocking minority ownership (more than 33 percent but not more than 50 percent of shares) and legal minority ownership (at least 10 but not more than 33 percent of shares). Majority ownership grants the owner the right to staff management and supervisory boards, alter and/or transfer firms' assets and adopt most crucial strategic decisions at general shareholders' meeting. Through management and supervisory boards, majority ownership allows also more direct executive control over the company.

The blocking minority ownership gives the right to block a number of decisions, such as those related to increasing or reducing assets and implementing major changes in business activities that the majority shareholder may strive to implement at the general shareholders' meeting.

Finally, legal minority ownership is potentially important since the law entitles the holder of such a stake to call the general shareholders' meeting and obstruct its decisions by delaying their implementation through lengthy court proceedings. Effective legal minority shareholders 
(including the state) may thus use their ownership position to delay or completely block the implementation of decisions by stronger shareholder(s). Another effect is observed in the case of portfolio companies that are primarily interested in capital gains. These companies have been observed to buy 10 percent positions in firms where they can sell the stake at a premium to the dominant shareholder whose business strategy is to avoid excessive scrutiny by an institutionally strong minority shareholder.

We are also able to distinguish whether or not the government keeps a golden share that gives it the right to veto certain managerial decisions, such as subject of business activities, termination of provided services, sales of assets, etc. Institutional evidence suggests that the golden share may be an important mechanism enabling the state to exert a degree of influence over firms in which it no longer holds a sufficient ownership stake. ${ }^{11}$

Finally, note that we cannot trace ownership stakes of less than 10 percent since their reporting is not required by law. This limitation is not particularly constraining for our analysis for two reasons. First, ownership stakes below 10 percent do not provide the holder with substantial direct control over management or the firms' assets (see also Kocenda and Valachy, 2002). Second, by having data on all owners with 10 percent or more ownership, we are able to estimate the effects of the most relevant degrees of dispersion of ownership, ranging from no owner having majority ownership, to no owner having the legal (10 percent) minority ownership.

\section{Types of Ownership}

Most empirical work about the impact of ownership has focused on government versus

\footnotetext{
11 The golden share was introduced by Act No. 210/1993, modifying Act No. 92/1991. The act set the conditions for property transfer from the state to others with the aim of protecting special interests of the state in firms privatized in large privatization. The veto rights associated with the golden share usually relate to the scope and line of business activity and depend on each company's charter. When the state sells its golden share, it gives up its rights in the company and the golden share cease to exist. The instrument of golden share in the Czech Republic does not conform fully to that found in other countries since it is limited to being solely an instrument of state control and does not serve as means of attracting free or less expensive credit.
} 


\section{William Davidson Institute Working Paper 471}

private ownership, domestic versus foreign ownership and ownership by insiders (managers and workers) versus outsiders. While useful as a first-order approximation, a finer division that reflects the patterns observed in the real world is needed to arrive at a clear understanding of the effects of ownership and corporate governance. Our analysis, based on six types of domestic and two types of foreign ownership, which are likely to have differing implications for objectives, constraints and other aspects of corporate governance, provides a step in this direction.

The six domestic types of owners whose effect we analyze are industrial company, bank, investment fund, individual, portfolio company, and state, while the two types of foreign owners are industrial company and all other owners. ${ }^{12}$ The ownership of a firm by an industrial company is normally expected to increase profitability through cost cutting, vertical or horizontal integration of activities, and possibly expansion aimed at exploiting economies of scale. However, in the incomplete legal and institutional framework of a transition, this proposition might not be empirically supported, especially if the parent company's management appropriated the acquired company's profits and assets (tunneling) or if it used the company for tax evasion or other private purposes.

A bank's ownership or credit exposure to a firm should also impose pressure on management to improve the firm's profitability (Cornelli, Portes, and Schaffer, 1996). However, the few, newly-created, large banks suddenly found themselves holding important credit and/or ownership positions in hundreds of firms and had only limited ability to staff the firms' management and supervisory boards with capable individuals. Moreover, the banks' ownership role was weakened by laws and a regulations that limited their authority and tolerated corruption

\footnotetext{
${ }^{12}$ Since insiders have not been important in the Czech Republic, we do not analyze this type of ownership.
} 


\section{William Davidson Institute Working Paper 471}

(see Lízal and Kocenda, 2001). The effect of bank ownership on performance is hence an empirical question.

Investment funds are likely to emphasize on profit and, depending on their time horizon, they may also emphasize sound corporate governance. However, since the investment funds created in Czech privatization resemble mutual funds, one may expect them to focus on increasing the value of the stocks held in their portfolios rather than pursuing issues of corporate governance. Iskander and Chamlou (2000, p.75) critically point out that corporate governance in the funds themselves has been weak. While the funds have followed short-term value maximization strategies through building up strategic stakes in large companies and selling controlling blocks at premium prices, they have often used the controlling stake to extract benefits from the company at the expense of minority shareholders.

Individual ownership is widely perceived as an ideal form of corporate governance with the residual claimant having very strong incentives to monitor the management.

The portfolio companies in the Czech Republic have tended to pursue short-term capital gains and they have normally not participated in corporate governance. While the experience in advanced market economies indicates that portfolio companies owning significant stakes often force management to become more profitable, it is not clear that this aspect of performance would be found in the post privatization period.

The state as an owner may pursue various goals, including economic efficiency, tax revenues, or social goals such as employment. The results of Gupta et al. (2000) suggest that revenue maximization was important in the privatization phase, but other goals, such as employment generation, may be important in the post privatization phase when unemployment went up. 


\section{William Davidson Institute Working Paper 471}

Finally, in a country with favorable profit repatriation rules, foreign owners are likely to aim at generating profits and, if the local products can be sold through the worldwide network, also on increasing output and hence employment.

\section{The Data and Basic Statistics}

We perform our analysis on annual rates of change of four key performance variables: operating profit, sales revenue, labor cost, and liability/equity ratio (financial leverage). Our working data set contains 2,529-2,949 of these annual rates of change observations on an unbalanced panel of 1,372-1,539 medium and large firms from all economic sectors. The exact number of observations and firms varies across the four performance indicators (see Table 1). The observations represent a cleaned data set from the entire population of firms that were listed on the Prague Stock Exchange (PSE) sometime in the 1996-1999 period. Thus, our data set contains firms that were listed on the PSE during the entire 1996-1999 period, as well those that started on the PSE sometime during 1996-1999 and later were de-listed. De-listing did not eliminate a firm from the sample and the sample size therefore does not diminish over time. Since virtually all large and medium-sized firms privatized in large scale privatization were listed on PSE, the data set contains most of these firms. In addition to performance variables, the data set contains detailed measures of ownership structure, sector in which the firm operates, and the firm's privatization history. It was compiled by the authors from information provided by Aspekt, a commercial database, The Prague Stock Exchange, The National Property Fund of the Czech Republic, and the Business Register of the Czech Republic.

As is known from empirical studies on transition and emerging market economies, firmlevel data often suffer from accounting deficiencies and they usually contain missing values and outlier observations that may bias the estimated coefficients (e.g., Filer and Hanousek, 2002). Firms operating in the Czech Republic started adopting international accounting (IAP) standards 


\section{William Davidson Institute Working Paper 471}

in 1992 and our discussions with international accounting firms located in the country indicate that this process was by and large completed in 1995. Our 1996-99 data are hence from a period in which IAP already dominated local accounting standards. Moreover, the data are reported by firms that had to conform to the standards demanded in the second half of the 1990s by the main regulatory institutions, namely the Prague Stock Exchange, The National Property Fund (the privatization agency) of the Czech Republic and the Czech National Bank. The data are hence relatively reliable and free from the accounting deficiencies that plague earlier studies.

We have adopted a three-step approach to handling missing observations and outliers in the original data set of $3040,2648,2972$, and 3056 year-to-year, rate of change observations for profit, sales, labor cost, and financial leverage, respectively. First, we eliminated the few (rate of change) observations that were based on inconsistent values in the levels of variables, such as negative values of sales, labor cost, and financial leverage. This resulted in 3040, 2644, 2972, and 2923 observations for the rate of change of profit, sales, labor cost, and financial leverage, respectively.

Second, since the data still contained a number of observations with fairly extreme values, we examined the sensitivity of parameter estimates to the trimming of these extreme values of variables, identifying points where the results became relatively insensitive to further trimming. We found that the estimates ceased being sensitive to trimming at the point where the year-to-year rate of change in the performance indicators was constrained to the wide interval of $(-300 \%, 300 \%)$ for profit and $(-100 \%, 300 \%)$ for the other three indicators. ${ }^{13}$ Imposing these wide limits resulted in a relatively modest reduction in the number of observations for the rate of change in profit, sales, labor cost, and liability/equity ratio to 2529, 2592, 2949, and 2883,

\footnotetext{
${ }^{13}$ In contrast, the estimated coefficients change dramatically and non-monotonically as we add the outlying observations beyond this borderline to the sample.
} 


\section{William Davidson Institute Working Paper 471}

respectively. We have used Heckman's (1979) procedure to correct for the possible sample selection bias brought about by the two-step data cleaning procedure. ${ }^{14}$

Third, we explored the possibility of creating a balanced data set with the same firm-year pairs across the four performance indicators. We found that this would require reducing the number of rate of change observations for profit, sales, labor cost, and financial leverage by 508 (20\%), 571 (22\%), $928(31.5 \%)$, and 862 (30\%), respectively, resulting in a sample with 1199 firms and 2021 observations. We have considered this further reduction in the number of observations to be excessively large. We have hence used the larger sample from step two above, but we have also generated Heckman-corrected estimates based on the balanced sub-sample for comparison. The findings based on the balanced sub-sample are broadly similar to those based on the larger sample.

Overall, as may be seen from Table 1, within the four-year (1996-99) period we have on average data available for three consecutive years to compute annual rates of change of performance variables. In terms of the number of firms and observations, our sample is larger than samples used in previous and most ongoing studies in this area. We have also carried out a number of checks against official and private records to verify that our ownership information was reliable and that we hence met the criticism of earlier privatization studies raised by Filer and Hanousek (2002).

As may be seen in Table 2, domestic industrial companies are the most frequent single largest owners (SLOs) with 1,102 observations, followed by domestic investment funds (493 observations), domestic individuals (311) and the Czech state (211). Foreign industrial companies are by far the most frequent SLOs among the foreign investors (202 observations),

\footnotetext{
${ }^{14}$ In particular, using the original set of observations we first ran a Heckman-type probit equation, predicting the probability that a given observation is included in the subsample on the basis of the following variables: the initial values of the performance indicators and their squares and products, as well as dummy variables capturing the presence of a given firm in a particular privatization wave.
} 


\section{William Davidson Institute Working Paper 471}

and the total number of foreign SLO observations (258) is similar to the number of state and domestic individual SLOs. Ownership concentration, measured by the average stake held by a SLO, is between 31 and 56 percent, which is rather high in comparison to ownership concentration in developed countries (Demsetz and Lehn, 1985). It resembles more the continental European than Anglo-American ownership concentration patterns (Brzica and Olson, 2001). Finally, as may be seen in panel B of Table 2, foreign owners as a group tend to hold majority ownership stakes in firms. The situation is just the opposite for domestic private owners and the state, both of which have average stakes around 40 percent and display absolutely and relatively more cases of blocking as well as legal minority ownership than majority ownership. Moreover, the state retains a golden share primarily in firms in which it or domestic private owners are the SLO. Finally, there are 47 observations with highly dispersed ownership in the sense that no type of owner has even a legal (10 percent) minority ownership (not shown in Table 2).

\section{The Econometric Model}

Our basic empirical specification represents a natural extension of the firm-specific fixed effects model used by Frydman, Gray, Hessel, and Rapaczynski (1999). In particular, let $X_{i j t}$ be a given performance indicator, with subscript $i$ denoting individual firm under a certain type of ownership $j$, as defined in the previous section, and $t$ denoting a time period (year). Moreover, let $y_{i j t}$ be the percentage change of $X$ from period $t-1$ to period $t, P_{i j t}$ the ownership type of firm $i$ in year $t$, and $D_{c t}$ a vector of annual dummy variables. Frydman et al. (1999) estimate a firmspecific fixed effects model of the form

$$
y_{i j t}=\alpha_{i}+P_{i j t} \beta_{j}+D_{c t} \delta_{c t}+\varepsilon_{i j t},
$$

where the rate of change of performance of a given firm is related to its ownership status and the annual dummy variables $D_{c t}$ that proxy for annual effects such as country-specific macro 


\section{William Davidson Institute Working Paper 471}

shocks. ${ }^{15}$ Using vector notation and suppressing subscript $j$ for the sake of simplicity, the model may be rewritten as:

$$
y_{i, t}=\alpha_{i}+\boldsymbol{\beta}^{\prime} \boldsymbol{p}_{i, t}+\boldsymbol{d}^{\prime} \boldsymbol{d}_{\boldsymbol{c t}}+\varepsilon_{i, t} .
$$

The specification in equations (1) and (1') assumes that the rate of change of firm's performance depends only on its ownership status and annual macro shocks. ${ }^{16}$

We start with a basic model that relates the annual rate of change in firm's performance, $y_{i, t}$, to its ownership at the start of the previous period, $\boldsymbol{p}_{i, t-1}$, its initial level of performance after large-scale privatization has been completed, $X_{i l}$, annual and industry/sector dummies, and dummy variables indicating whether the firm was privatized in the first or second wave of the voucher scheme or outside of it (all captured in the vector of dummy variables $\boldsymbol{d}$ ):

$$
y_{i, t}=\alpha_{0}+\boldsymbol{\beta}^{\prime} \boldsymbol{p}_{i, t-1}+\gamma X_{i, 1}+\boldsymbol{d}^{\prime} \boldsymbol{d}+\varepsilon_{i, t} .
$$

Note that ownership $\boldsymbol{p}_{i, t-1}$ is lagged one period and that our data reflect both the initial (1996) post-privatization ownership and all subsequent ownership changes. Initial post-privatization level of performance, $X_{i l}$, refers to 1996 -- one year after large-scale privatization was officially concluded. Our specification in equation (2) thus controls for inter-firm differences in the initial post-privatization conditions, such as firm size, for industry-specific technological and other effects that may affect performance, and for differences between firms that were or were not part of the voucher scheme. As we discuss below, these variables control for potential selectivity as firms with different performance potential may have been channeled to different parts of the

\footnotetext{
15 The model in equation (1) is developed in Ashenfelter and Card (1985) and Heckman and Hotz (1989).

${ }^{16}$ Frydman et al. (1999) also estimate an ownership-group fixed effects model of the form $y_{i j t}=\alpha_{j}+P_{j i t} \beta_{j}+X_{i j t-1} \gamma+D_{c t} \delta_{c t}+\varepsilon_{i j t}$ where $a_{j}$ represents the fixed effect common to all firms $i$ of ownership $j$. Note that the group fixed effects model does not control for firm heterogeneity within ownership groups and that it may yield biased estimates if this heterogeneity is present (e.g., if better firms within each group are privatized first, as indicated by Gupta et al., 2000). Note also that the model in equation (1) is not a direct extension of the group-specific fixed effects model to one based on firm-specific fixed effects since equation (1) omits $X_{i j t-1}$. The estimates from the two models are hence not directly comparable.
} 


\section{William Davidson Institute Working Paper 471}

privatization program, which in turn may have affected their initial performance after privatization.

Equation (2) may be viewed as coming from a framework such as the one invoked in the endogenous growth literature, where the rate of change of the dependent variable may depend on its initial level (e.g., rate of change of performance being related to an initial level of investment). Alternatively, the equation may be thought of as constituting the first difference of a logarithmic model of performance:

$\ln X_{i, t}=\alpha_{0 i}+\alpha_{0} t+\boldsymbol{\beta}^{\prime}(t \cdot \boldsymbol{p})_{i, t-1}+\gamma\left(t \cdot X_{i, 1}\right)+\boldsymbol{d}^{\prime}(t \cdot \boldsymbol{d})+?_{i, t}$,

where the logarithm of the level of performance, $\ln X_{i, t}$, depends on firm-specific fixed effects and several variables (ownership, $\boldsymbol{p}$, initial post-privatization performance, $X_{i, 1}$, and annual, industry and privatization wave dummies, $\boldsymbol{d}$ ), whose effect on performance evolves linearly through time. Equation (2) then represents an approximation of the first difference of equation (3). ${ }^{17}$

An interesting feature of our data is that we are able to explore the effect of ownership forms in two key directions. First, we can examine whether majority, blocking minority and legal minority ownership of a particular type affects the firm's post-privatization performance. We can also assess if the state can affect performance by retaining a golden share that gives it the right to block certain managerial decisions. Second, we can assess the performance effect associated with different types of single largest owners, and whether the SLOs have a majority, blocking minority, or legal minority stake. The ability to distinguish these ownership forms enables us to carry out the analysis to an important level of institutional detail that has not been achieved before.

${ }^{17}$ In particular, $y_{i t}$ is approximated by $\ln X_{i, t}-\ln X_{i, t-1}=\alpha_{0}+\boldsymbol{\beta}^{\prime} \boldsymbol{p}_{i, t-1}+\gamma X_{i, 1}+\boldsymbol{d}^{\prime} \boldsymbol{d}+\boldsymbol{\varepsilon}_{i, t}$ which is our basic specification in equation (2), with $?_{i, t}-?, i, t-1=e_{i, t}$. 


\section{William Davidson Institute Working Paper 471}

\section{Extent of Ownership}

As we discussed in Section 3, the analysis of the effect of majority and blocking minority ownership is important because these categories of ownership are widely believed to have major effects on corporate go vernance and performance of firms. Assessing the effect of legal minority is also important because it is an easier ownership stake to obtain and it carries important legal rights that may influence corporate governance and performance.

Since the relative performance of state, domestic private and foreign ownership is one of the major issues in the privatization debate in the context of emerging as well as advanced market economies, we first focus our analysis on these three categories of ownership. In particular, we allow corporate performance to depend on whether private domestic owners as a group, foreign owners as a group, or the state have a majority, $\boldsymbol{m}$, blocking minority, $\boldsymbol{b}$, or legal

minority, $\boldsymbol{l}$, share ownership in the firm, and we also account for the effect of the state retaining a golden share, $g$ :

$y_{i, t}=\alpha_{0}+?_{1}^{\prime} \boldsymbol{m}_{i, t-1}+?_{2}^{\prime} \boldsymbol{b}_{i, t-1}+?_{3}^{\prime} \boldsymbol{l}_{i, t-1}+\psi_{4} s_{i, t-1}+\theta g_{i, t-1}+\gamma X_{i, 1}+d^{\prime} d+\varepsilon_{i, t}$.

In equation (4), the dummy variables are coded so that the constant represents majority state ownership and the effect of other ownership forms is measured relative to this base. This is an intuitively appealing way to specify the equation since firms in which the state retains majority ownership and control are the ones that are the least privatized and on average probably also the least transformed. The dummy variable $s$ contains all other ownership patterns that do not involve a majority or blocking or legal minority stake in the firm. The specification in (4) thus allows us to distinguish firms that went from state ownership into a variety of ownership forms and to compare the performance effects of these ownership forms relative to the effect of state majority ownership. 


\section{William Davidson Institute Working Paper 471}

Another important issue that arises in the context of post-privatization behavior of firms is the dynamics of their restructuring and performance. The performance effect of short-term (defensive or reactive) restructuring is for instance often hypothesized to differ from the medium-term (strategic) restructuring associated with different forms of ownership (e.g., Blanchard, 1997, Roland, 2000). Moreover, strategic restructuring may take time to carry out and it may hence have a performance effect that varies over time. Blanchard (1997) has for example hypothesized that the effect of privatization would tend to have a U-shaped effect on employment and there may be a non-linear effect on other variables as well. Since there is no guidance for an exact functional form to capture the variation of the main effects over time, we use the first two terms of a second-order Taylor series expansion. Hence, we estimate a model that allows the effects of the various ownership forms described above to vary linearly and quadratically with time, where time is measured as the number of years since 1996:

$$
\begin{aligned}
y_{i, t}= & \alpha_{0}+\alpha_{1} t+\alpha_{2} t^{2}+?_{1}{ }_{1} \boldsymbol{m}_{i, t-1}+\boldsymbol{t}_{1}{ }^{\prime}(t \cdot \boldsymbol{m})_{i, t-1}+\boldsymbol{t}_{2}{ }^{\prime}\left(t^{2} \cdot \boldsymbol{m}\right)_{i, t-1}+ \\
& +\boldsymbol{?}_{2}{ }^{\prime} \boldsymbol{b}_{i, t-1}+\boldsymbol{t}_{3}{ }^{\prime}(t \cdot \boldsymbol{b})_{i, t-1}+\boldsymbol{t}_{4}{ }^{\prime}\left(t^{2} \cdot \boldsymbol{b}\right)_{i, t-1}+?_{3}{ }_{3} \boldsymbol{l}_{i, t-1}+\boldsymbol{t}_{5}{ }^{\prime}(t \cdot \boldsymbol{l})_{i, t-1}+\boldsymbol{t}_{6}{ }^{\prime}\left(t^{2} \cdot \boldsymbol{l}\right)_{i, t-1}+ \\
+ & \psi_{4} s_{i, t-1}+\tau_{7}(t \cdot s)_{i, t-1}+\tau_{8}\left(t^{2} \cdot s\right)_{i, t-1}+ \\
& +\theta g_{i, t-1}+\tau_{9}(t \cdot g)_{i, t-1}+\tau_{10}\left(t^{2} \cdot g\right)_{i, t-1}+\gamma X_{i, 1}+\boldsymbol{d}^{\prime} \boldsymbol{d}+\varepsilon_{i, t}
\end{aligned}
$$

\section{The Single Largest Owner}

In the above analysis, we focus on the effects of majority and blocking or legal minority ownership, irrespective of how many different owners comprise the majority or minority groups. Highly concentrated and widely dispersed ownership levels of a given type are hence assumed to have the same effect on performance, a feature that may be too restrictive in view of the aforementioned theoretical controversy in this area. In the second prong of our analysis, we therefore focus on the effects of the single largest owner (SLO) and we exploit the fact that our 


\section{William Davidson Institute Working Paper 471}

data permit us to distinguish among eight different types of SLOs as well as the extent of their ownership.

The basic specification in this analysis is identical to that given in equation (2) above, with $\boldsymbol{p}$ being now a vector of eight different types of SLO. The corresponding specification for time-varying effects adds interaction terms of $\boldsymbol{p}$ with a linear and quadratic time trend:

$$
y_{i, t}=\alpha_{0}+\alpha_{1} t+\alpha_{2} t^{2}+\boldsymbol{\beta}^{\prime} \boldsymbol{p}_{i, t-1}+?_{1}{ }^{\prime}(t \cdot \boldsymbol{p})_{i, t-1}+?_{2}{ }^{\prime}\left(t^{2} \cdot \boldsymbol{p}\right)_{i, t-1}+\gamma X_{i, 1}+\boldsymbol{d}^{\prime} \boldsymbol{d}+\varepsilon_{i, t}
$$

We next allow corporate performance to depend not only on the type of the SLO, $\boldsymbol{p}$, but also on whether the SLO has a majority, $\boldsymbol{m}^{*}$, blocking minority, $\boldsymbol{b}^{*}$, or legal minority, $\boldsymbol{l}^{*}$, ownership of the firm, and whether the government has a golden share $g$. The specification that allows for these effects takes the form:

$$
y_{i, t}=\alpha_{0}+\boldsymbol{\beta}^{\prime} \boldsymbol{p}_{i, t-1}+?_{1}{ }_{1}^{\prime} \boldsymbol{m}_{i, t-1}^{*}+?_{2}{ }^{\prime} \boldsymbol{b}_{i, t-1}^{*}+?_{3}{ }^{\prime} \boldsymbol{l}_{i, t-1}^{*}+\theta_{4} g_{i, t-1}+\gamma X_{i, 1}+\boldsymbol{d}^{\prime} \boldsymbol{d}+\varepsilon_{i, t} \text {. }
$$

Given that we have eight categories of SLOs, a specification that corresponds to (7) and includes an interaction with linear and quadratic time-varying effects is very extensive. Moreover, since many estimated coefficients in the more parsimonious models are insignificant, the extensive specification would likely generate mostly insignificant higher-order coefficients. We hence conclude our analysis by reporting the results of a fairly general yet simpler specification that nests equations (6) and (7) and allows us to assess the relative importance of interacting the various categories of SLO with time, versus allowing for the SLO to have a majority or blocking or legal minority status, and for the state to retain a golden share:

$$
\begin{aligned}
y_{i, t}= & \alpha_{0}+\alpha_{1} t+\alpha_{2} t^{2}+\boldsymbol{\beta}^{\prime} \boldsymbol{p}_{i, t-1}+\boldsymbol{?}_{1}{ }^{\prime}(t \cdot \boldsymbol{p})_{i, t-1}+?_{2}{ }^{\prime}\left(t^{2} \cdot \boldsymbol{p}\right)_{i, t-1}+ \\
& +?_{1}{ }^{\prime} \boldsymbol{m}_{i, t-1}^{*}+?_{2}{ }^{\prime} \boldsymbol{b}_{i, t-1}^{*}+?_{3}{ }^{\prime} \boldsymbol{l}_{i, t-1}^{*}+\theta_{4} g_{i, t-1}+\gamma X_{i, 1}+\boldsymbol{d}^{\prime} \boldsymbol{d}+\varepsilon_{i, t} .
\end{aligned}
$$

As mentioned earlier, since the firms in our sample were privatized in the large-scale privatization program, both within and outside the voucher scheme that occurred in two waves, 


\section{William Davidson Institute Working Paper 471}

they may display systematic heterogeneity since Gupta et al. (2000) found that better performing firms tended to be privatized in the first wave. Moreover, firms privatized earlier have a longer post-privatization period before we observe them in our data in 1996. To control for the potential selectivity bias stemming from these phenomena, we have included as regressors in the rates of change equations dummy variables indicating whether the firm was privatized in the first or second wave of the voucher scheme or outside of it (within large-scale privatization in general), the level of performance of the firm after large-scale privatization in 1996, and industry/sector dummy variables (vector $\boldsymbol{d}$ ). ${ }^{18}$ As it turns out, the estimated coefficients on the privatization dummy variables are insignificant in most the regressions.

We have also employed the Kruskat-Wallis (1952) test to check for differences in the 1996-99 variation of the performance variables of firms from the first and second wave of the voucher scheme, as well as the difference in each of these sets of firms and those privatized outside of the voucher scheme. The test is consistent with most of the regression findings in that it does not find the variation in the growth rates of variables for all three sub-samples to be different from one another.

Finally, as to the method of estimation, we report estimates that are generated by the Huber (1967)-White (1982) (heteroskedasticity-adjusted) least squares, corrected for sample selection.

\section{Empirical Results}

In Table 3 we present the estimated coefficients of the basic model given by equation 4 , in which the rate of change in each performance indicator is related to dummy variables indicating whether domestic private owners, foreign owners or the state have a majority, blocking or legal

\footnotetext{
${ }^{18}$ When expressed as a model of the determinants of the level of firm performance, along the lines of equation (3), it is clear that the present specification controls for firm-specific fixed effects and allows the above dummy variables and the 1996 performance variable to control for systematic linear differences in post-privatization performance over time.
} 


\section{William Davidson Institute Working Paper 471}

minority ownership of the firm, and whether the state keeps a golden share in the firm. The constant reflects the 1996-97 rate of change in performance of firms that were privatized outside of the voucher scheme, in which the state retains majority ownership, and which operate in the miscellaneous ("other") category of the 19 industries for which we control. The estimated coefficients on the various forms of ownership represent the average annual ownership effects relative to the effect of majority state ownership. ${ }^{19}$

As may be seen from Table 3, none of the categories of concentration of private domestic or foreign ownership generates an effect on the rate of change of sales revenue that differs from that of the majority state-owned firms. This is a provocative finding because it has been widely believed that domestic and foreign private ownerships, especially in greater intensities, lead to more substantial strategic restructuring and increases in sales -- domestically and/or on the world markets. We have checked the sensitivity of the result in Table 3 and we find that the results are robust except that majority foreign ownership generates an 11 percent positive effect on sales with additional trimming of about 10 percent of observations with the most extreme values of sales.

Ownership effects are significant with respect to the three other performance variables. Majority and blocking minority domestic and foreign ownerships are associated with systematic

\footnotetext{
${ }^{19}$ Since our specification employs industry and annual dummy variables, and uses state majority ownership as part of the base that makes up the regression constant, it provides a convenient way to measure the average effects (across years and industries) of various forms of ownership, relative to the majority ownership by state. However, the specification does not lend itself to expressing in a simple way the average effect of state majority ownership since this effect varies across industries and years. To provide the reader with an estimate of the average effect of state majority ownership, we have therefore also estimated a more parsimonious model in which state majority ownership forms the constant and in which there are no annual, industry and privatization form dummy variables. In this model, the constant provides an estimate of the average effect of state majority ownership. These estimates show that the state as a majority owner is associated with a 5.9 and 11.4 annual percentage point growth of labor cost and financial leverage, respectively. It does not engender a significant change in profitability and sales. When the state is in a blocking minority position in a firm, it is associated with a 10.4 percent annual reduction in financial leverage. The state is also associated with an additional 4.1 and 5.3 percentage point increase in sales and labor cost, respectively, and 3.5 percentage point reduction of financial leverage in firms in which it has retained a golden share. The state hence demonstrates socially-oriented tendency in contributing to increasing labor costs.
} 


\section{William Davidson Institute Working Paper 471}

27-37 percent (log point) increases in the annual rate of increase of profitability, relative to state majority ownership. There is also a 24 percent positive effect on profitability associated with legal minority domestic ownership and a 57 log point effect associated with highly dispersed (other than majority or minority) ownership. ${ }^{20}$ These results hence suggest that moderately and highly concentrated private domestic and foreign forms of ownership increase firm profitability relative to all degrees of concentration of state ownership. However, highly dispersed ownership, with no owner having a 10 percent or higher stake, has the highest positive effect on profit. This finding provides support to the theories claiming that dispersed private ownership, giving autonomy to managers, is most beneficial for corporate performance.

The positive effect of domestic majority and blocking minority ownership on profitability coincides with a negative 6 percent effect of these types of ownership on the rate of change of the labor cost. Firms with domestic majority and blocking minority owners hence restructure, at least in part, by reducing their labor cost - the only categories of owners to do so. The firms with foreign majority and blocking minority ownership display no effect on labor cost, and neither do firms in which domestic owners have a legal minority or firms with dispersed ownership. These firms presumably generate higher profitability by reducing non-labor costs and/or generating income from other sources than sales (e.g., rental income, dividends from stock ownership, interenterprise credit, and, as we discuss presently, reduction in debt service). Finally, firms in which the state retains a golden share register a 5 percent increase in the annual rate of increase in labor costs, thus providing further evidence that the state pursues at least in part a social objective. Since the state retains golden shares primarily in state-owned and domestic private firms (Table

\footnotetext{
${ }^{20}$ For the sake of simplicity, in the text we report the logarithmic coefficients as percentage effects. This approximation is quite accurate for coefficient values between zero and about 0.3 , but it is less accurate for higher values. For instance, the percentage effect corresponding to the coefficient of 0.57 (57 log points) is given by $[\exp (0.57)]-1=77 \%$.
} 


\section{William Davidson Institute Working Paper 471}

2), the effect of golden share moderates the tendency of firms with domestic majority and blocking minority ownership to reduce their labor cost.

The regression on financial leverage shows that firms with majority, blocking minority and legal minority foreign ownership, as well as majority domestic owned firms, have a negative effect on the liability/equity ratio, relative to firms with majority state ownership and all other types of firms.

The estimates in Table 3 have several interesting implications about the behavior of firms in the medium-term period after privatization. First, both private domestic and foreign majority and blocking minority owners increase profitability relative to majority state-owned firms. Domestic firms do so at least in part by reducing the rate of growth of labor cost. The foreign firms presumably do so by reducing non-labor costs or generating income from other areas than sales revenues, including possibly lower debt service payments. None of the nine types of firms (except for majority foreign owned firms in the additionally trimmed sample) succeed in increasing the scale of production as evidenced by the insignificant effects on sales. This suggests that the 0.8 percent average annual rate of increase in sales reported in Table 1 reflects fairly uniformly the behavior of all ownership categories of firms. Hence, rather than carrying out strategic restructuring characterized by increased profitability through greater production and sales, firms with all types of ownership appear to engage in defensive restructuring (reducing labor and presumably also non-labor costs) and generating income from other sources. The positive sales effect associated with majority foreign ownership in the more aggressively trimmed sample indicates that foreign owners in firms that do not show major changes in sales revenues are the only ones that restructure by expanding production in the post-privatization period. Since the positive sales effect in the additionally trimmed sample is not accompanied by a positive effect on labor costs, it appears to be associated with increased productive efficiency 


\section{William Davidson Institute Working Paper 471}

or mark-ups. Finally, foreign owners with all intensities of ownership uniformly reduce financial leverage of firms that they own. Majority domestic ownership has the same effect.

The estimates in Table 4 correspond to equation (5) and they capture the dynamics of the ownership effects over time. The insignificant overall effect of all types of ownership on sales revenue, reported in Table 3, is found also in the time-varying-coefficient model in Table 4. The uniform sales effect of all ownership forms is hence persistent over time. It is also insensitive to further trimming of the sample. The strong overall effects of several forms of ownership on profitability, found in Table 3, are not detected in the more flexible specification of Table 4, which suffers from multicollinearity. ${ }^{21}$ In contrast, we find a significant effect of the golden share on productivity. The effect is concave, ising first and declining later on. Finally, the insignificant overall effect of foreign legal minority ownership (Table 3) is found to be composed of a positive initial effect that declines over time.

The effect of ownership on labor cost varies strongly over time. Firms with majority and legal minority foreign ownership, blocking and legal minority domestic ownership, and golden share all display a U-shaped effect on labor cost over time. These owners hence engage in defensive restructuring in the first four years after privatization, but the effect withers away over time. These results are supportive of the assertion made by Blanchard (1997) that the effect of restructuring will have a U-shape over time.

Finally, the dynamic effect on the liability/equity ratio is initially negative and increasing linearly over time for majority and legal minority domestic ownership, as well as for dispersed (other than majority or minority) ownership and for the golden share. Majority state ownership is associated with a linearly declining financial leverage, and the overall negative effects of all

\footnotetext{
${ }^{21}$ The multicollinearity proble $\mathrm{m}$ is also present in a linear time-varying-coefficient model.
} 


\section{William Davidson Institute Working Paper 471}

forms of foreign ownership, found in Table 3, are not observable in the flexible specification of Table 4.

In Tables 5-7, we report the performance effects of a given owner being the single largest owner (SLO) of the firm. The estimates in Table 5 correspond to equation (2) and they show a positive effect on the annual rate of increase in profit when the SLO is a domestic industrial company (a 17 percent effect), domestic investment fund (a 17 percent effect), domestic individual owner (a 20 percent effect), and foreign industrial company (a 17 percent effect). Domestic bank and portfolio companies, as well as foreign "other" (i.e., non-industrial) company SLO do not have profit effects that are different from the effect of a state SLO. In the case of domestic industrial company and investment fund SLOs, the positive profit effect coincides with a reduction in the labor cost, ${ }^{22}$ while the positive profit effect of the foreign industrial company SLO is concomitant with a positive effect on sales revenue and negative effect on leverage. The positive profit effect of an individual owner also coincides with a negative effect on leverage.

Classifying ownership by the eight SLO categories therefore provides complementary results to the categorization by majority, blocking and legal minority and golden share ownership. The positive profit effect in Table 3 of majority and blocking minority domestic private ownership, associated with a reduction in the labor cost, is reflected in Table 5 in the behavior of domestic industrial companies and investment funds as SLOs. The positive profit effect among firms with majority and blocking minority foreign owners in Table 3 translates into the positive profit effect of the foreign industrial SLOs in Table $5 .^{23}$ The positive effect of foreign industrial companies on sales in Table 5 corresponds to the positive sales effect among the additionally trimmed sample reported on in the context of Table 3 above. A slightly weaker

\footnotetext{
${ }^{22}$ The domestic industrial company registers also a marginally significant negative effect on sales. Since the effect of this type of ownership on profit is positive, the negative sales effect seems to be dominated by the negative effect on labor cost and possibly also on non-labor cost or other than sales income.

${ }^{23}$ The foreign industrial SLOs constitute the majority of our foreign ownership observations (Table 2).
} 


\section{William Davidson Institute Working Paper 471}

correspondence is found for domestic individual SLOs that show a positive profit effect and a negative and almost conventionally significant effect on labor cost. It is possible that these firms also increase profit by reducing non-labor costs. Finally, as in Table 3, the effect of foreign ownership on financial leverage in Table 5 is negative and statistically significant for both the industrial and non-industrial foreign firms.

In Table 6, we report the dynamic performance effects of the eight categories of SLOs. There are relatively few significant time-varying coefficients and they are almost all concentrated in the labor cost column. Thus domestic individual SLOs and both types of foreign SLOs display a U-shaped adjustment in labor cost over time, corresponding to Blanchard's (1997) hypothesis. The only other effect is an inverted U effect of the domestic individual SLO on sales.

The estimates in Table 7 correspond to equation (7) and they examine whether the SLO effect depends on majority or minority ownership. As may be seen from the table, there are relatively few instances in which SLO's majority or minority stakes play a part and the lack of significance is not brought about by collinearity. Foreign industrial SLOs tend to reduce the labor cost irrespective of the size of their stake, domestic investment funds, the state and foreign other SLOs do so when they have a majority stake, and domestic industrial company, individual owner, state, and other foreign SLOs do so when they have a blocking minority. Furthermore, the state as a majority SLO has a negative effect on profit, while a blocking minority by a domestic portfolio company and the state have negative effects on sales revenue and profitability. Finally, legal minority stakes by domestic portfolio company and the state both reduce sales revenue and the state also has a significant negative effect on profitability. ${ }^{24}$

\footnotetext{
${ }^{24}$ Finally, we have also estimated equation (8), in which we allow the performance effects of SLOs to depend on both time and extent of ownership. This specification confirms a number of the previous findings, but it also weakens the significance of some of the earlier estimates and does not provide new insights.
} 


\section{William Davidson Institute Working Paper 471}

\section{Concluding Observations}

Compared to other studies of the effect of ownership on performance, our analysis is of interest because we (a) have detailed information on the forms and concentration of ownership in a virtually complete population of medium and large firms privatized in a model large-scale privatization economy, (b) use a four-year panel of data that come from the post privatization period when one can observe medium-term effects corresponding to strategic restructuring, (c) have data conforming to the international accounting system, and (d) control systematically for potential sample selection bias.

We use the detailed ownership data to estimate the performance effect of ownership along two important dimensions: (i) the degree of concentration of domestic private, foreign and state ownership, irrespective of the number of owners within each of these ownership categories and (ii) eight principal types of single largest owners (SLOs) and the concentration of ownership by these SLOs.

Our empirical findings have several key implications. First, none of the categories of concentration of private domestic or foreign ownership generates an effect on the rate of change of sales revenue that differs from that of the majority or significant minority state-owned firms. These results hence lead one to reject the hypothesis that domestic and/or foreign private ownership, in moderate or greater concentrations, leads to more substantial strategic restructuring as reflected in increased sales. (The exception is majority foreign-owned firms in a more aggressively trimmed sample where we find a positive sales effect.)

Second, private domestic and foreign majority and significant minority owners, as well as dispersed owners, increase profitability relative to majority and significant minority state-owned firms. The domestic private firms do so at least in part by reducing the rate of growth of labor cost, while the foreign firms, domestic private firms with small concentration and firms with 


\section{William Davidson Institute Working Paper 471}

dispersed ownership presumably do so by reducing non-labor costs or generating income from other areas than sales revenues. Hence, rather than increasing profitability through greater sales, private domestic and foreign firms appear to do so through defensive restructuring (reducing labor and presumably also non- labor costs) and by generating income from other sources.

Third, firms with dispersed ownership register higher positive effect on profit than firms with more concentrated ownership of any kind. This finding provides support to the theories arguing that factors such as stock market liquidity and managerial autonomy and initiative, rather than control of managers by strong shareholders or state, are important for firm performance.

Fourth, the state through its retention of a golden share (ability to veto certain managerial decisions), as well as through its base effect as a majority shareholder, has a positive effect on the labor cost. The state hence displays a 'social' objective during the post privatization period when unemployment rose.

Fifth, foreign owners with high as well as moderate extent of ownership uniformly reduce financial leverage, as do majority domestic owners. This implies that significant private domestic and foreign ownership results in a reduction of debt and/or infusion of equity capital and it may represent one of the avenues of increasing profitability in these firms.

Sixth, the dynamic (time-varying-coefficient) estimates of the effects of ownership suffer from collinearity, but the effect on labor cost appears to be U-shaped, which supports a restructuring hypothesis advanced by Blanchard (1997) and others.

Seventh, analyzing the effect of ownership through the eight types of single largest owners provides complementary results to those from the domestic private, foreign and state ownership categories. Single largest ownership by domestic and foreign industrial companies and domestic investment funds and individuals results in higher profits, while domestic bank and portfolio company ownership, or foreign 'other' ownership, do not. Banks and portfolio 


\section{William Davidson Institute Working Paper 471}

companies as SLOs have therefore been incapable of carrying out profit-generating restructuring. The banks' inability appears to be connected with the fact that the few large banks suddenly found themselves holding significant ownership positions in hundreds of firms and were unable to staff the firms' management and supervisory boards with capable individuals. Their ownership role was also complicated by laws and regulations that limited their rights. The portfolio companies in turn usually pursued short-term gains, which was often at odds with the task of carrying out strategic restructuring.

Eighth, the positive profit effect of a foreign industrial company SLO is associated with a positive effect on sales and a reduction in financial leverage. These foreign SLOs hence carry out strategic restructuring in production and financing without deviating from the state ownership benchmark in terms of the labor cost.

Ninth, the effect of SLO by and large does not vary with the SLO's concentration of ownership. This evidence goes against all the leading theories related to the effect of concentrated or dispersed ownership on performance. It suggests that for certain measures of ownership, such as the SLO, the extent of concentration or dispersion does not affect performance.

Overall, our study shows that in the post-privatization period, private ownership tends to be associated with superior performance, relative to state ownership, in terms of some indicators but not in terms of others. Some forms of private ownership (e.g., banks and portfolio companies) are particularly ineffective in exceeding performance standards of state-owned companies. Our study also finds that dispersed ownership results in better or equal performance than more concentrated ownership forms, thus providing evidence for an important theoretical debate. 


\section{References}

Angelucci, M., S. Estrin, J. Konings, and Z. Zólkiewski. 2001. "The Effect of Ownership and Competitive Pressure on Firm Performance in Transition Countries: Micro Evidence from Bulgaria, Romania and Poland", CEPR Discussion Paper DP2985, London.

Aghion, P., and W. Carlin. 1996. Restructuring Outcomes and the Evolution of Ownership Patterns in Central and Eastern Europe. Economics of Transition, 4(2), 371-88.

Aghion, P., and J. Tirole. 1997. "Formal and Real Authority in Organizations ", Journal of Political Economy, 55: 1-27.

Ashenfelter, O., and Card, D. 1985. "Using the Longitudinal Structure of Earnings to Estimate the Effect of Training Programs". Review of Economics and Statistics 67(4), 648-60.

Barberis, N., M. Boycko, A. Shleifer and N. Tsukanova. 1996. "How Does Privatization Work? Evidence from the Russian Shops." Journal of Political Economy 104, 764-90.

Bevan, A., S. Estrin and M. Schaffer. 1999. Determinants of Enterprise Performance during Transition. Centre for Economic Reform and Transformation (CERT) Working Paper 99/03.

Bilsen, V. and J. Konings. 1998. "Job Creation, Job Destruction, and Growth of Newly Established, Privatized, and State-Owned Enterprises in Transition Economies: Survey Evidence from Bulgaria, Hungary, and Romania”, Journal of Comparative Economics, 26 (1998): 429-445

Blanchard, O. 1997. The Economics of Post-Communist Transition. Oxford: Oxford University Press.

Bolton, P., and E-L. von-Thadden. 1998. "Blocks, Liquidity, and Corporate Control". Journal of Finance, 53(1), 1-25.

Bornstein, M. 2001. "Post-privatisation enterprise restructuring", Post-Communist Economies 13: (2) $189-203$.

Brzica, D. and Olsson, M. 2001. "Corporate governance in transitional economies: the case of the Czech Republic", paper presented at the ACE workshop on Corporate Governance and the Accession Countries, Portoroz, Slovenia, June, 2001.

Carlin, W., S. Fries, M.E. Schaffer, and P. Seabright. 2001. "Competition and Enterprise Performance in Transition Economies: Evidence from a Cross-country Survey", CEPR Discussion Paper DP2840, London.

Caves, D.W. and L. Christensen. 1980. "The Relative Efficiency of Public and Private Firms in a Competitive Environment: The Case of Canadian Railroads," Journal of Political Economy, 88 (5), 958-76.

Claessens, S. and S. Djankov. 1999. "Ownership Concentration and Corporate Performance in the Czech Republic." Journal of Comparative Economics 27 498-513.

Coffee, J. 1996. Institutional Investors in Transitional Economies: Lessons from the Czech Experience. In: Frydman, R., Gray, C., and Rapaczynski, A. (eds.): Corporate governance in Central Europe and Russia. Volume 1. Banks, funds, and foreign investors. Budapest, Central European University Press 1996, s. 111-86.

Cornelli, F., Portes R., and Schaffer M. E. 1996. The Capital Structure of Firms in Central and Eastern Europe. CEPR Discussion Paper No. 1392.

Demsetz, H. and K. Lehn. 1985. The Structure of Corporate-Ownership - Causes and Consequences. Journal of Political Economy 93: (6) 1155-1177.

Djankov, S. and Murrell, P. 2000. The Determinants of Enterprise Restructuring in Transition: An Assessment of the Evidence. Washington, D.C.: World Bank. 
Filer, R. K. and J. Hanousek. 2002. "Data Watch: Research Data from Transition Economies." Journal of Economic Perspectives 16, 1, 225-240.

Frydman, R., C.W. Gray, M. Hessel and A. Rapaczynski. 1999. "When does Privatization Work? The Impact of Private Ownership on Corporate Performance in Transition Economies." Quarterly Journal of Economics 114: 1153-91.

Frydman, R., M. Hessel and A. Rapaczynski. 2000. Why Ownership Matters? Entrepreneurship and the Restructuring of Enterprises in Central Europe. C.V. Starr Center for Applied Economics Working Paper, NYU, New York.

Grosfeld, I. and J.F. Nivet. 1997. "Firm's Heterogeneity in Transition: Evidence From a Polish Panel Data Set," William Davidson Institute Working Paper No.47, 1997.

Grosfeld, I. and Roland, G. 1997. "Defensive and Strategic Restructuring in Central European Enterprises." Journal of Transforming Economies and Societies, 3(4): 21-46.

Grosfeld, I. and T. Tressel. 2001. "Competition and Corporate Governance: Substitutes or Complements? Evidence from the Warsaw Stock Exchange," William Davidson Institute WP No. 369.

Gupta, N., J. C. Ham, and J. Svejnar. 2000. Priorities and Sequencing in Privatization: Theory and Evidence from the Czech Republic. William Davidson Institute WP No. 323.

Heckman, J. 1979. Sample selection bias as a specification error. Econometrica 47: 153-161

Heckman, J., and Hotz, V. 1989. "Chosing among Alternative Nonexperimental Methods for Estimating the Impact of Social Programs: The Case of Manpower Training". Journal of the American Statistical Association 84(408), 862-74.

Holmström, B., and J. Tirole. 1983. "Market liquidity and performance monitoring", Journal of Political Economy, 101: 678-709.

Huber, P. J. 1967. The behavior of maximum likelihood estimates under nonstandard conditions. Proceedings of the Fifth Berkeley Symposium on Mathematical Statistics and Probability, 221-223. Berkeley, CA: University of California Press.

Iskander, M. R. and N. Chamlou. 2000. Corporate governance: A framework for implementation. World Bank, Washington, D.C.

Kocenda, E.: Residual State Property in the Czech Republic. Eastern European Economics, 37, 1999, 5, 6-35.

Kocenda, E., and Valachy, J. 2002. Firm Ownership Structures: Dynamic Development. Prague Economic Papers, 11, 3.

Kotrba, J.: Privatization Process in the Czech Republic: Players and Winners, pp. 159-198. In Svejnar, J., The Czech Republic and economic transition in Eastern Europe. San Diego; London and Toronto: Harcourt Brace, Academic Press, 1995.

Kotrba, J. and J. Svejnar. 1994. Rapid and Multifaceted Privatization: Experience of the Czech and Slovak Republics. Nomisma/Most, 147-185.

Kruskal, W. H. and W.A. Wallis. 1952. Use of ranks in one-criterion variance analysis. Journal of the American Statistical Association 47: 583-621.

Lízal, L. and E. Kocenda. 2001. State of Corruption in Transition: The Case of the Czech Republic. Emerging Markets Review, 2, 2, 138-160.

Lízal, L. and J. Svejnar. 2002. "Investment, Credit Rationing, and the Soft Budget Constraint: Evidence from Czech Panel Data," The Review of Economics and Statistics, 84(2), 353370.

Megginson, W.L. and Netter JR. 2001 "From state to market: A survey of empirical studies on privatization", Journal of Economic Literature 39: (2) 321-389, June 2001. 
Pohl, G., R. Anderson, S. Claessens, and S. Djankov. 1997. Privatization and Restructuring in Central and Eastern Europe: Evidence and Policy Options. World Bank Technical Paper No. 368.

Roland, G. Transition and Economics: Politics, Markets and Firms. Cambridge, MA: MIT Press, 2000.

Sachs, Jeffrey, Clifford Zinnes and Yair Eilat. 2000. The Gains from Privatization in Transition Economies: Is Change of Ownership Enough? CAER II Discussion Paper 63, Harvard Institute for International Development, Cambridge, MA.

Shirley, Mary and Patrick Walsh. 2000. Public versus Private Ownership: The Current State of the Debate. The World Bank, Washington, DC, 2000.

Shleifer, A., R. and Vishny. 1997. "A Survey of Corporate Governance", Journal of Finance, 52(2): 737-783.

Smith, S., B. Cin, and M. Vodopivec. 1997. Privatization Incidence, ownership Forms, and Firm Performance: Evidence from Slovenia. Journal of Comparative Economics, 25, 158-179.

Svejnar, Jan and Miroslav Singer. 1994. Using Vouchers to Privatize an Economy: The Czech and Slovak Case. Economics of Transition 2, 43-64.

White, H. 1982. Maximum likelihood estimation of misspecified models. Econometrica 50: 1-25. 
William Davidson Institute Working Paper 471

Table 1

Summary Statistics: Growth Rates of Performance Measures 1996-1999

\begin{tabular}{lcccccc}
\hline \hline & Mean & $\begin{array}{c}\text { Std. } \\
\text { Dev. }\end{array}$ & Min & Max & $\begin{array}{c}\text { Num. } \\
\text { Firms }\end{array}$ & Num.Obs \\
& & & & & & \\
\hline Operating Profit & 0.109 & 1.023 & -2.995 & 2.998 & 1497 & 2529 \\
Sales & 0.008 & 0.427 & -1.000 & 2.820 & 1371 & 2592 \\
Labor Costs & 0.010 & 0.364 & -1.000 & 2.842 & 1539 & 2949 \\
Liability/ Equity & 0.078 & 0.331 & -0.812 & 2.885 & 1497 & 2883 \\
\hline \hline
\end{tabular}

Number of firms differs from number of observations due to the panel structure.

The ratio of the number of observations to number of firms varies due to an unbalanced nature of the panel. 


\section{William Davidson Institute Working Paper 471}

\section{Table 2}

Summary Statistics: Ownership Measures

Panel A: Ownership by SLO

\begin{tabular}{|c|c|c|c|c|c|c|}
\hline \multirow[b]{2}{*}{$\begin{array}{l}\text { Type of single largest } \\
\text { owner (SLO) }\end{array}$} & \multirow[b]{2}{*}{$\begin{array}{l}\text { Num. } \\
\text { of obs. }\end{array}$} & \multirow{2}{*}{$\begin{array}{c}\text { Mean } \\
\text { size of } \\
\text { stake }(\%)\end{array}$} & \multicolumn{4}{|c|}{ Number of Observations } \\
\hline & & & $\begin{array}{l}\text { Majority } \\
\text { held by } \\
\text { SLO }\end{array}$ & $\begin{array}{c}\text { Blocking } \\
\text { Minority held } \\
\text { by SLO }\end{array}$ & $\begin{array}{l}\text { Legal } \\
\text { Minority }\end{array}$ & $\begin{array}{c}\text { Golden } \\
\text { Share held } \\
\text { by State }\end{array}$ \\
\hline \multicolumn{7}{|l|}{ Domestic Ownership } \\
\hline Industrial Co. & 1102 & 45.87 & 441 & 363 & 283 & 31 \\
\hline Bank & 53 & 42.57 & 19 & 10 & 22 & 2 \\
\hline Invest. Fund & 493 & 30.79 & 68 & 97 & 317 & 26 \\
\hline Individual & 311 & 35.58 & 66 & 82 & 159 & 16 \\
\hline Portfolio Co. & 98 & 38.35 & 19 & 35 & 41 & 6 \\
\hline State & 277 & 40.37 & 66 & 101 & 105 & 75 \\
\hline \multicolumn{7}{|l|}{ Foreign Ownership } \\
\hline Industrial Co. & 202 & 55.92 & 119 & 48 & 29 & 3 \\
\hline Others & 56 & 45.77 & 18 & 20 & 17 & 1 \\
\hline Total & 2592 & 41.61 & 816 & 756 & 973 & 160 \\
\hline
\end{tabular}

Panel B: Grouped Ownership by Type

\begin{tabular}{lcccccc}
\hline & & & \multicolumn{3}{c}{ Number of observations } \\
\cline { 5 - 7 } $\begin{array}{l}\text { Type of aggregate } \\
\text { ownership }\end{array}$ & $\begin{array}{c}\text { Num. } \\
\text { of obs. }\end{array}$ & $\begin{array}{c}\text { Mean } \\
\text { size of } \\
\text { stake }(\%)\end{array}$ & Majority & $\begin{array}{c}\text { Blocking } \\
\text { Minority }\end{array}$ & $\begin{array}{c}\text { Legal } \\
\text { Minority }\end{array}$ & $\begin{array}{c}\text { Golden } \\
\text { Share held } \\
\text { by State }\end{array}$ \\
\hline Domestic & 2057 & 40.26 & 613 & 587 & 822 & 81 \\
Foreign & 258 & 53.72 & 137 & 68 & 46 & 4 \\
State & 277 & 40.37 & 66 & 101 & 973 & 75 \\
\hline Total & 2592 & 41.61 & 816 & 756 & 205 \\
\hline \hline
\end{tabular}

Note: Table contains basic ownership statistics associated with performance variable of sales. 
Table 3

Average Effects of Domestic Private, Foreign and State Ownership.

\begin{tabular}{|c|c|c|c|c|}
\hline & $\begin{array}{c}\text { Operating } \\
\text { Profit }\end{array}$ & Sales & $\begin{array}{c}\text { Labor } \\
\text { Cost }\end{array}$ & $\begin{array}{c}\text { Liability/ } \\
\text { Equity }\end{array}$ \\
\hline Constant (Majority State) & $\begin{array}{l}-0.707^{1} \\
(0.186)\end{array}$ & $\begin{array}{r}0.051 \\
(0.084)\end{array}$ & $\begin{array}{c}0.089 \mathbf{1 0} \\
(0.051)\end{array}$ & $\begin{array}{l}-0.175^{1} \\
(0.036)\end{array}$ \\
\hline \multicolumn{5}{|l|}{ Owner Type } \\
\hline Majority Domestic & $\begin{array}{c}0.315^{1} \\
(0.115)\end{array}$ & $\begin{array}{r}-0.074 \\
(0.059)\end{array}$ & $\begin{array}{l}-0.0611^{10} \\
(0.032)\end{array}$ & $\begin{array}{l}-0.063^{\mathbf{5}} \\
(0.028)\end{array}$ \\
\hline Majority Foreign & $\begin{array}{c}0.282^{5} \\
(0.136)\end{array}$ & $\begin{array}{r}0.061 \\
(0.065)\end{array}$ & $\begin{array}{r}0.040 \\
(0.038)\end{array}$ & $\begin{array}{l}-0.145^{1} \\
(0.042)\end{array}$ \\
\hline Blocking Minority Domestic & $\begin{array}{c}0.268^{5} \\
(0.117)\end{array}$ & $\begin{array}{c}-0.087 \\
(0.059)\end{array}$ & $\begin{array}{l}-0.062^{5} \\
(0.031)\end{array}$ & $\begin{array}{r}-0.045 \\
(0.029)\end{array}$ \\
\hline Blocking Minority Foreign & $\begin{array}{c}0.367^{5} \\
(0.161)\end{array}$ & $\begin{array}{c}-0.025 \\
(0.070)\end{array}$ & $\begin{array}{r}-0.007 \\
(0.037)\end{array}$ & $\begin{array}{l}-0.073^{10} \\
(0.039)\end{array}$ \\
\hline Blocking Minority State & $\begin{array}{r}0.134 \\
(0.127)\end{array}$ & $\begin{array}{r}-0.036 \\
(0.060)\end{array}$ & $\begin{array}{r}0.005 \\
(0.031)\end{array}$ & $\begin{array}{r}-0.047 \\
(0.030)\end{array}$ \\
\hline Legal Minority Domestic & $\begin{array}{r}0.243^{5} \\
(0.114)\end{array}$ & $\begin{array}{c}-0.055 \\
(0.059)\end{array}$ & $\begin{array}{r}-0.033 \\
(0.030)\end{array}$ & $\begin{array}{r}-0.043 \\
(0.028)\end{array}$ \\
\hline Legal Minority Foreign & $\begin{array}{c}-0.086 \\
(0.168)\end{array}$ & $\begin{array}{r}-0.070 \\
(0.073)\end{array}$ & $\begin{array}{r}0.035 \\
(0.055)\end{array}$ & $\begin{array}{l}-0.066^{10} \\
(0.037)\end{array}$ \\
\hline Legal Minority State & $\begin{array}{r}0.110 \\
(0.145)\end{array}$ & $\begin{array}{r}-0.054 \\
(0.065)\end{array}$ & $\begin{array}{r}0.014 \\
(0.040)\end{array}$ & $\begin{array}{r}-0.033 \\
(0.032)\end{array}$ \\
\hline Other than Majority or Minority & $\begin{array}{r}0.568 \\
(0.158) \\
\end{array}$ & $\begin{array}{r}0.137 \\
(0.117) \\
\end{array}$ & $\begin{array}{r}0.091 \\
(0.057) \\
\end{array}$ & $\begin{array}{r}-0.023 \\
(0.039) \\
\end{array}$ \\
\hline Golden Share & $\begin{array}{r}0.044 \\
(0.093) \\
\end{array}$ & $\begin{array}{r}0.007 \\
(0.023) \\
\end{array}$ & $\begin{array}{r}0.053^{1} \\
(0.019) \\
\end{array}$ & $\begin{array}{r}0.005 \\
(0.016) \\
\end{array}$ \\
\hline Initial value & $\begin{array}{c}-1.2 \mathrm{E}-08 \\
(2.1 \mathrm{E}-08) \\
\end{array}$ & $\begin{array}{r}3.0 \mathrm{E}-10 \\
(1.9 \mathrm{E}-09) \\
\end{array}$ & $\begin{array}{r}9.5 \mathrm{E}-09 \\
(7.3 \mathrm{E}-09) \\
\end{array}$ & $\begin{array}{c}-1.9 \mathrm{E}-02{ }^{1} \\
(7.2 \mathrm{E}-03) \\
\end{array}$ \\
\hline First Wave & $\begin{array}{r}0.124 \\
(0.122)\end{array}$ & $\begin{array}{r}0.042 \\
(0.067)\end{array}$ & $\begin{array}{r}-0.079 \\
(0.054)\end{array}$ & $\begin{array}{c}0.1822^{1} \\
(0.034)\end{array}$ \\
\hline Second Wave & $\begin{array}{r}0.065 \\
(0.126)\end{array}$ & $\begin{array}{r}0.056 \\
(0.067)\end{array}$ & $\begin{array}{l}-0.104^{10} \\
(0.053)\end{array}$ & $\begin{array}{r}0.134^{1} \\
(0.033)\end{array}$ \\
\hline Both Waves & $\begin{array}{r}0.125 \\
(0.134) \\
\end{array}$ & $\begin{array}{r}0.069 \\
(0.069) \\
\end{array}$ & $\begin{array}{r}-0.081 \\
(0.056)\end{array}$ & $\begin{array}{r}0.168 \\
(0.037)\end{array}$ \\
\hline Inverse of Mills' Ratio & $\begin{array}{r}0.608^{1} \\
(0.142)\end{array}$ & $\begin{array}{c}-0.030^{\mathbf{5}} \\
(0.014)\end{array}$ & $\begin{array}{r}-0.005 \\
(0.008)\end{array}$ & $\begin{array}{r}0.407^{1} \\
(0.018)\end{array}$ \\
\hline
\end{tabular}

Note: Numbers in parenthesis are heteroscedasticity consistent standard errors. 1, 5 and 10 denote significance at $1 \%, 5 \%$ and $10 \%$ level, two-tail test, respectively. Industry, year, and privatization dummies included. All estimates are adjusted for potential sample selection bias using the Heckman (1979) procedure. 
William Davidson Institute Working Paper 471

Table 4

Dynamic Effects of Domestic Private, Foreign and State Ownership.

\begin{tabular}{|c|c|c|c|c|}
\hline & $\begin{array}{c}\text { Operating } \\
\text { Profit }\end{array}$ & Sales & $\begin{array}{c}\text { Labor } \\
\text { Cost }\end{array}$ & $\begin{array}{l}\text { Liability/ } \\
\text { Equity }\end{array}$ \\
\hline Constant (Majority State) & $\begin{array}{r}-0.203 \\
(0.860) \\
\end{array}$ & $\begin{array}{r}0.101 \\
(0.268)\end{array}$ & $\begin{array}{l}-0.201 \\
(0.141)\end{array}$ & $\begin{array}{r}0.082 \\
(0.128)\end{array}$ \\
\hline \multicolumn{5}{|l|}{ Owner Type } \\
\hline Majority Domestic & $\begin{array}{r}-0.147 \\
(0.898)\end{array}$ & $\begin{array}{r}-0.244 \\
(0.282)\end{array}$ & $\begin{array}{r}0.034 \\
(0.176)\end{array}$ & $\begin{array}{l}-0.328^{5} \\
(0.141)\end{array}$ \\
\hline Majority Foreign & $\begin{array}{r}0.948 \\
(1.014)\end{array}$ & $\begin{array}{r}0.205 \\
(0.343)\end{array}$ & $\begin{array}{r}0.536^{\mathbf{5}} \\
(0.219)\end{array}$ & $\begin{array}{r}-0.217 \\
(0.255)\end{array}$ \\
\hline Blocking Minority Domestic & $\begin{array}{r}-0.419 \\
(0.907)\end{array}$ & $\begin{array}{r}-0.200 \\
(0.283)\end{array}$ & $\begin{array}{r}0.29810 \\
(0.159)\end{array}$ & $\begin{array}{r}-0.212 \\
(0.145)\end{array}$ \\
\hline Blocking Minority Foreign & $\begin{array}{r}-0.191 \\
(1.286)\end{array}$ & $\begin{array}{r}-0.091 \\
(0.379)\end{array}$ & $\begin{array}{r}0.204 \\
(0.199)\end{array}$ & $\begin{array}{r}-0.073 \\
(0.233)\end{array}$ \\
\hline Blocking Minority State & $\begin{array}{r}0.189 \\
(1.045)\end{array}$ & $\begin{array}{r}0.179 \\
(0.282)\end{array}$ & $\begin{array}{r}0.161 \\
(0.168)\end{array}$ & $\begin{array}{r}-0.227 \\
(0.162)\end{array}$ \\
\hline Legal Minority Domestic & $\begin{array}{r}-0.252 \\
(0.885)\end{array}$ & $\begin{array}{r}-0.254 \\
(0.279)\end{array}$ & $\begin{array}{r}0.184 \\
(0.154)\end{array}$ & $\begin{array}{l}-0.25310 \\
(0.136)\end{array}$ \\
\hline Legal Minority Foreign & $\begin{array}{l}2.2915 \\
(1.163)\end{array}$ & $\begin{array}{r}0.355 \\
(0.395)\end{array}$ & $\begin{array}{r}0.7801 \\
(0.296)\end{array}$ & $\begin{array}{r}-0.321 \\
(0.219)\end{array}$ \\
\hline Legal Minority State & 1.091 & 0.045 & -0.142 & -0.25310 \\
\hline Other than Majority or Minority & $\begin{array}{r}(1.086) \\
-0.393\end{array}$ & $\begin{array}{r}(0.309) \\
0.486\end{array}$ & $\begin{array}{r}(0.294) \\
0.230\end{array}$ & $\begin{array}{l}(0.151) \\
-0.443 \quad 10\end{array}$ \\
\hline Golden Share & $\begin{array}{l}(1.190) \\
-1.076 \mathbf{1 0} \\
(0.586)\end{array}$ & $\begin{array}{r}(1.098) \\
-0.064 \\
(0.128) \\
\end{array}$ & $\begin{array}{r}(0.386) \\
0.2975 \\
(0.121) \\
\end{array}$ & $\begin{array}{l}(0.231) \\
-0.15910 \\
(0.095)\end{array}$ \\
\hline $\begin{array}{l}\text { Time } \\
\quad \text { Majority Domestic }\end{array}$ & $\begin{array}{r}0.561 \\
(1.143)\end{array}$ & $\begin{array}{r}0.157 \\
(0.287)\end{array}$ & $\begin{array}{r}-0.137 \\
(0.192)\end{array}$ & $\begin{array}{l}0.28410 \\
(0.161)\end{array}$ \\
\hline Majority Foreign & $\begin{array}{r}-0.715 \\
(1.270)\end{array}$ & $\begin{array}{r}-0.175 \\
(0.376)\end{array}$ & $\begin{array}{l}-0.5735 \\
(0.245)\end{array}$ & $\begin{array}{r}0.048 \\
(0.284)\end{array}$ \\
\hline Blocking Minority Domestic & $\begin{array}{r}0.936 \\
(1.156)\end{array}$ & $\begin{array}{r}0.099 \\
(0.294)\end{array}$ & $\begin{array}{l}-0.4215 \\
(0.172)\end{array}$ & $\begin{array}{r}0.174 \\
(0.166)\end{array}$ \\
\hline Blocking Minority Foreign & $\begin{array}{r}0.738 \\
(1.480)\end{array}$ & $\begin{array}{r}0.091 \\
(0.431)\end{array}$ & $\begin{array}{r}-0.230 \\
(0.226)\end{array}$ & $\begin{array}{r}-0.009 \\
(0.273)\end{array}$ \\
\hline Blocking Minority State & $\begin{array}{r}0.112 \\
(1.045)\end{array}$ & $\begin{array}{l}-0.292 \\
(0.282)\end{array}$ & $\begin{array}{r}-0.165 \\
(0.168)\end{array}$ & $\begin{array}{r}0.162 \\
(0.162)\end{array}$ \\
\hline Legal Minority Domestic & 0.643 & 0.208 & -0.28810 & 0.26710 \\
\hline Legal Minority Foreign & $\begin{array}{l}(1.132) \\
-2.53010\end{array}$ & $\begin{array}{r}(0.293) \\
-0.554\end{array}$ & $\begin{array}{l}(0.168) \\
-1.0021\end{array}$ & $\begin{array}{r}(0.157) \\
0.297\end{array}$ \\
\hline Legal Minority State & $\begin{array}{c}(1.465) \\
-1.386 \\
(1.371)\end{array}$ & $\begin{array}{r}(0.442) \\
-0.170 \\
(0.328)\end{array}$ & $\begin{array}{r}(0.382) \\
0.205 \\
(0.373)\end{array}$ & $\begin{array}{r}(0.274) \\
0.251 \\
(0.167)\end{array}$ \\
\hline Other than Majority or Minority & $\begin{array}{r}1.169 \\
(1.505)\end{array}$ & $\begin{array}{r}-0.617 \\
(1.522)\end{array}$ & $\begin{array}{r}-0.191 \\
(0.469)\end{array}$ & $\begin{array}{r}0.46810 \\
(0.279)\end{array}$ \\
\hline Golden Share & $\begin{array}{r}1.4205 \\
(0.692)\end{array}$ & $\begin{array}{r}0.020 \\
(0.157)\end{array}$ & $\begin{array}{c}-0.3165 \\
(0.155)\end{array}$ & $\begin{array}{r}0.18310 \\
(0.109)\end{array}$ \\
\hline Base (Majority State) & $\begin{array}{l}-0.650 \\
(1.092)\end{array}$ & $\begin{array}{r}0.007 \\
(0.258)\end{array}$ & $\begin{array}{c}0.3801 \\
(0.139)\end{array}$ & $\begin{array}{l}-0.2855 \\
(0.143)\end{array}$ \\
\hline
\end{tabular}


Table 4 (continued)

\begin{tabular}{|c|c|c|c|c|}
\hline & $\begin{array}{l}\text { Operating } \\
\text { Profit }\end{array}$ & Sales & $\begin{array}{c}\text { Labor } \\
\text { Cost }\end{array}$ & $\begin{array}{l}\text { Liability/ } \\
\text { Equity }\end{array}$ \\
\hline \multicolumn{5}{|l|}{ Time Square } \\
\hline Majority Domestic & $\begin{array}{r}-0.142 \\
(0.292)\end{array}$ & $\begin{array}{r}-0.021 \\
(0.072)\end{array}$ & $\begin{array}{r}0.038 \\
(0.047)\end{array}$ & $\begin{array}{r}-0.058 \\
(0.043)\end{array}$ \\
\hline Majority Foreign & $\begin{array}{r}0.163 \\
(0.324)\end{array}$ & $\begin{array}{r}0.054 \\
(0.094)\end{array}$ & $\begin{array}{c}0.1388^{5} \\
(0.059)\end{array}$ & $\begin{array}{r}0.003 \\
(0.071)\end{array}$ \\
\hline Blocking Minority Domestic & $\begin{array}{r}-0.265 \\
(0.296)\end{array}$ & $\begin{array}{r}-0.008 \\
(0.075)\end{array}$ & $\begin{array}{c}0.1025 \\
(0.042)\end{array}$ & $\begin{array}{r}-0.031 \\
(0.045)\end{array}$ \\
\hline Blocking Minority Foreign & $\begin{array}{r}-0.203 \\
(0.365)\end{array}$ & $\begin{array}{r}-0.016 \\
(0.108)\end{array}$ & $\begin{array}{r}0.052 \\
(0.058)\end{array}$ & $\begin{array}{r}0.012 \\
(0.069)\end{array}$ \\
\hline Blocking Minority State & $\begin{array}{r}-0.090 \\
(0.381)\end{array}$ & $\begin{array}{r}0.088 \\
(0.073)\end{array}$ & $\begin{array}{r}0.030 \\
(0.050)\end{array}$ & $\begin{array}{r}-0.016 \\
(0.057)\end{array}$ \\
\hline Legal Minority Domestic & $\begin{array}{r}-0.173 \\
(0.290)\end{array}$ & $\begin{array}{r}-0.038 \\
(0.075)\end{array}$ & $\begin{array}{r}0.078^{10} \\
(0.042)\end{array}$ & $\begin{array}{r}-0.066 \\
(0.043)\end{array}$ \\
\hline Legal Minority Foreign & $\begin{array}{r}0.579 \\
(0.378)\end{array}$ & $\begin{array}{r}0.159 \\
(0.110)\end{array}$ & $\begin{array}{r}0.2761 \\
(0.107)\end{array}$ & $\begin{array}{r}-0.066 \\
(0.071)\end{array}$ \\
\hline Legal Minority State & $\begin{array}{r}0.430 \\
(0.348)\end{array}$ & $\begin{array}{r}0.065 \\
(0.082)\end{array}$ & $\begin{array}{r}-0.057 \\
(0.094)\end{array}$ & $\begin{array}{r}-0.055 \\
(0.044)\end{array}$ \\
\hline Other than Majority or Minority & $\begin{array}{r}-0.298 \\
(0.393)\end{array}$ & $\begin{array}{r}0.224 \\
(0.484)\end{array}$ & $\begin{array}{r}0.053 \\
(0.127)\end{array}$ & $\begin{array}{r}-0.103 \\
(0.072)\end{array}$ \\
\hline Golden Share & $\begin{array}{l}-0.379^{\mathbf{5}} \\
(0.182)\end{array}$ & $\begin{array}{r}0.013 \\
(0.044)\end{array}$ & $\begin{array}{c}0.085^{5} \\
(0.042)\end{array}$ & $\begin{array}{r}-0.042 \\
(0.030)\end{array}$ \\
\hline Base (Majority State) & $\begin{array}{r}0.151 \\
(0.278) \\
\end{array}$ & $\begin{array}{r}-0.033 \\
(0.065)\end{array}$ & $\begin{array}{l}-0.1091 \\
(0.033)\end{array}$ & $\begin{array}{r}0.056 \\
(0.039)\end{array}$ \\
\hline Initial value & $\begin{array}{r}-1.0 \mathrm{E}-08 \\
(2.2 \mathrm{E}-08) \\
\end{array}$ & $\begin{array}{r}1.1 \mathrm{E}-09 \\
(1.9 \mathrm{E}-09) \\
\end{array}$ & $\begin{array}{r}1.3 \mathrm{E}-0810 \\
(7.7 \mathrm{E}-09)\end{array}$ & $\begin{array}{c}-1.9 \mathrm{E}-02{ }^{1} \\
(7.1 \mathrm{E}-03) \\
\end{array}$ \\
\hline \multicolumn{5}{|l|}{ Voucher-Privatization Dummies } \\
\hline First Wave & $\begin{array}{r}0.114 \\
(0.122)\end{array}$ & $\begin{array}{r}0.039 \\
(0.067)\end{array}$ & $\begin{array}{r}-0.075 \\
(0.053)\end{array}$ & $\begin{array}{r}0.176 \mathbf{1} \\
(0.033)\end{array}$ \\
\hline Second Wave & $\begin{array}{r}0.057 \\
(0.126)\end{array}$ & $\begin{array}{r}0.054 \\
(0.067)\end{array}$ & $\begin{array}{l}-0.101 \quad 10 \\
(0.053)\end{array}$ & $\begin{array}{r}0.1281 \\
(0.033)\end{array}$ \\
\hline Both Waves & $\begin{array}{r}0.115 \\
(0.133)\end{array}$ & $\begin{array}{r}0.065 \\
(0.070)\end{array}$ & $\begin{array}{r}-0.076 \\
(0.056)\end{array}$ & $\begin{array}{r}0.1591 \\
(0.037)\end{array}$ \\
\hline Inverse of Mills' Ratio & $\begin{array}{r}0.622^{1} \\
(0.141)\end{array}$ & $\begin{array}{l}-0.030^{5} \\
(0.014)\end{array}$ & $\begin{array}{r}-0.006 \\
(0.008)\end{array}$ & $\begin{array}{r}0.4071 \\
(0.018)\end{array}$ \\
\hline
\end{tabular}

Note: Numbers in parenthesis are heteroscedasticity consistent standard errors. 1, 5 and 10 denote significance at $1 \%, 5 \%$ and $10 \%$ level, two-tail test, respectively. Industry, year, and privatization dummies included. All estimates are adjusted for potential sample selection bias using the Heckman (1979) procedure. 
Table 5

Effects of Single Largest Owner (SLO) on Performance

\begin{tabular}{|c|c|c|c|c|}
\hline & $\begin{array}{l}\text { Operating } \\
\text { Profit }\end{array}$ & Sales & $\begin{array}{l}\text { Labor } \\
\text { Cost }\end{array}$ & $\begin{array}{l}\text { Liability/ } \\
\text { Equity }\end{array}$ \\
\hline Constant (State) & $\begin{array}{c}-0.587 \\
(0.166) \\
\end{array}$ & $\begin{array}{r}0.025 \\
(0.073) \\
\end{array}$ & $\begin{array}{c}0.105^{\mathbf{5}} \\
(0.050) \\
\end{array}$ & $\begin{array}{c}-0.198^{1} \\
(0.032)\end{array}$ \\
\hline \multicolumn{5}{|l|}{ Domestic Ownership } \\
\hline Industrial Co. & $\begin{array}{r}0.1722^{5} \\
(0.068)\end{array}$ & $\begin{array}{l}-0.048^{10} \\
(0.026)\end{array}$ & $\begin{array}{l}-0.069^{1} \\
(0.020)\end{array}$ & $\begin{array}{c}-0.016 \\
(0.014)\end{array}$ \\
\hline Bank & $\begin{array}{r}0.072 \\
(0.129)\end{array}$ & $\begin{array}{r}0.008 \\
(0.072)\end{array}$ & $\begin{array}{r}0.021 \\
(0.051)\end{array}$ & $\begin{array}{r}-0.062 \\
(0.042)\end{array}$ \\
\hline Invest. Fund & $\begin{array}{c}0.167^{5} \\
(0.078)\end{array}$ & $\begin{array}{r}-0.025 \\
(0.030)\end{array}$ & $\begin{array}{l}-0.096^{1} \\
(0.022)\end{array}$ & $\begin{array}{l}-0.020 \\
(0.015)\end{array}$ \\
\hline Individual & $\begin{array}{r}0.196 \\
(0.086)\end{array}$ & $\begin{array}{r}0.000 \\
(0.036)\end{array}$ & $\begin{array}{r}-0.040 \\
(0.028)\end{array}$ & $\begin{array}{l}-0.031^{10} \\
(0.018)\end{array}$ \\
\hline Portfolio Co. & $\begin{array}{r}0.120 \\
(0.128)\end{array}$ & $\begin{array}{r}-0.042 \\
(0.054)\end{array}$ & $\begin{array}{r}-0.007 \\
(0.051)\end{array}$ & $\begin{array}{l}-0.028 \\
(0.029)\end{array}$ \\
\hline \multicolumn{5}{|l|}{ Foreign Ownership } \\
\hline Industrial Co. & $\begin{array}{r}0.171 \\
(0.090)\end{array}$ & $\begin{array}{r}0.066^{5} \\
(0.033)\end{array}$ & $\begin{array}{r}0.026 \\
(0.024)\end{array}$ & $\begin{array}{l}-0.083^{1} \\
(0.028)\end{array}$ \\
\hline Others & $\begin{array}{r}-0.013 \\
(0.143) \\
\end{array}$ & $\begin{array}{r}-0.021 \\
(0.062) \\
\end{array}$ & $\begin{array}{r}-0.052 \\
(0.047) \\
\end{array}$ & $\begin{array}{c}-0.066^{1} \\
(0.025) \\
\end{array}$ \\
\hline Initial value & $\begin{array}{r}-2.0 \mathrm{E}-08 \\
(2.1 \mathrm{E}-08) \\
\end{array}$ & $\begin{array}{r}1.2 \mathrm{E}-09 \\
(1.7 \mathrm{E}-09) \\
\end{array}$ & $\begin{array}{r}1.1 \mathrm{E}-08 \\
(7.6 \mathrm{E}-09) \\
\end{array}$ & $\begin{array}{l}-2.0 \mathrm{E}-02^{1} \\
(7.4 \mathrm{E}-03) \\
\end{array}$ \\
\hline \multicolumn{5}{|c|}{ Voucher-Privatization Dummies } \\
\hline First Wave & $\begin{array}{r}0.119 \\
(0.123)\end{array}$ & $\begin{array}{r}0.031 \\
(0.066)\end{array}$ & $\begin{array}{r}-0.080 \\
(0.053)\end{array}$ & $\begin{array}{c}0.183^{1} \\
(0.033)\end{array}$ \\
\hline Second Wave & $\begin{array}{r}0.065 \\
(0.126)\end{array}$ & $\begin{array}{r}0.047 \\
(0.066)\end{array}$ & $\begin{array}{l}-0.101^{10} \\
(0.053)\end{array}$ & $\begin{array}{c}0.132 \\
(0.033)\end{array}$ \\
\hline Both Waves & $\begin{array}{r}0.126 \\
(0.135)\end{array}$ & $\begin{array}{r}0.058 \\
(0.068)\end{array}$ & $\begin{array}{c}-0.072 \\
(0.056)\end{array}$ & $\begin{array}{c}0.171^{1} \\
(0.037)\end{array}$ \\
\hline Inverse of Mills' Ratio & $\begin{array}{r}0.601 \\
(0.147)\end{array}$ & $\begin{array}{l}-0.030^{5} \\
(0.014)\end{array}$ & $\begin{array}{r}-0.006 \\
(0.008)\end{array}$ & $\begin{array}{r}0.408^{1} \\
(0.018)\end{array}$ \\
\hline
\end{tabular}

Note: Numbers in parenthesis are heteroscedasticity consistent standard errors. 1, 5 and 10 denote significance at $1 \%, 5 \%$ and $10 \%$ level, two-tail test, respectively. Industry, year, and privatization dummies included. All estimates are adjusted for potential sample selection bias using the Heckman (1979) procedure. 
Table 6

Dynamic Effects of SLO

\begin{tabular}{|c|c|c|c|c|}
\hline & $\begin{array}{c}\text { Operating } \\
\text { Profit }\end{array}$ & Sales & $\begin{array}{l}\text { Labor } \\
\text { Cost }\end{array}$ & $\begin{array}{c}\text { Liability/ } \\
\text { Equity }\end{array}$ \\
\hline Constant (State) & $\begin{array}{r}-0.224 \\
(0.478) \\
\end{array}$ & $\begin{array}{r}0.126 \\
(0.134) \\
\end{array}$ & $\begin{array}{r}-0.141 \\
(0.114) \\
\end{array}$ & $\begin{array}{c}-0.148^{\mathbf{5}} \\
(0.071) \\
\end{array}$ \\
\hline \multicolumn{5}{|c|}{ Owner Type } \\
\hline \multicolumn{5}{|c|}{ Domestic Ownership } \\
\hline Industrial Co. & $\begin{array}{c}-0.159 \\
(0.493)\end{array}$ & $\begin{array}{r}-0.224 \\
(0.143)\end{array}$ & $\begin{array}{r}0.087 \\
(0.125)\end{array}$ & $\begin{array}{r}-0.007 \\
(0.080)\end{array}$ \\
\hline Bank & $\begin{array}{r}-0.736 \\
(0.699)\end{array}$ & $\begin{array}{r}-0.986 \\
(0.819)\end{array}$ & $\begin{array}{r}0.177 \\
(0.391)\end{array}$ & $\begin{array}{r}-0.221 \\
(0.230)\end{array}$ \\
\hline Invest. Fund & $\begin{array}{r}-0.189 \\
(0.553)\end{array}$ & $\begin{array}{c}-0.119 \\
(0.169)\end{array}$ & $\begin{array}{r}0.124 \\
(0.142)\end{array}$ & $\begin{array}{r}-0.120 \\
(0.093)\end{array}$ \\
\hline Individual & $\begin{array}{r}-0.612 \\
(0.606)\end{array}$ & $\begin{array}{c}-0.551 \\
(0.236)\end{array}$ & $\begin{array}{r}0.270 \\
(0.188)\end{array}$ & $\begin{array}{r}0.116 \\
(0.117)\end{array}$ \\
\hline Portfolio Co. & $\begin{array}{r}0.165 \\
(0.850) \\
\end{array}$ & $\begin{array}{r}0.047 \\
(0.301) \\
\end{array}$ & $\begin{array}{r}-0.319 \\
(0.419) \\
\end{array}$ & $\begin{array}{r}-0.164 \\
(0.173) \\
\end{array}$ \\
\hline \multicolumn{5}{|c|}{ Foreign Ownership } \\
\hline Industrial Co. & $\begin{array}{r}0.787 \\
(0.632)\end{array}$ & $\begin{array}{r}0.294 \\
(0.196)\end{array}$ & $\begin{array}{c}0.395^{\mathbf{5}} \\
(0.156)\end{array}$ & $\begin{array}{r}0.026 \\
(0.184)\end{array}$ \\
\hline Others & $\begin{array}{r}1.224 \\
(1.011) \\
\end{array}$ & $\begin{array}{r}-0.593 \\
(0.419) \\
\end{array}$ & $\begin{array}{r}0.603^{5} \\
(0.293) \\
\end{array}$ & $\begin{array}{r}-0.189 \\
(0.167) \\
\end{array}$ \\
\hline \multicolumn{5}{|l|}{ Time } \\
\hline \multicolumn{5}{|c|}{ Domestic Ownership } \\
\hline Industrial Co. & $\begin{array}{r}0.362 \\
(0.647)\end{array}$ & $\begin{array}{r}0.171 \\
(0.163)\end{array}$ & $\begin{array}{c}-0.209 \\
(0.156)\end{array}$ & $\begin{array}{r}0.010 \\
(0.098)\end{array}$ \\
\hline Bank & $\begin{array}{r}1.027 \\
(0.828)\end{array}$ & $\begin{array}{r}1.356 \\
(1.069)\end{array}$ & $\begin{array}{c}-0.199 \\
(0.489)\end{array}$ & $\begin{array}{r}0.135 \\
(0.260)\end{array}$ \\
\hline Invest. Fund & $\begin{array}{r}0.468 \\
(0.715)\end{array}$ & $\begin{array}{r}0.154 \\
(0.195)\end{array}$ & $\begin{array}{r}-0.271 \\
(0.175)\end{array}$ & $\begin{array}{r}0.138 \\
(0.115)\end{array}$ \\
\hline Individual & $\begin{array}{r}0.935 \\
(0.769)\end{array}$ & $\begin{array}{r}0.620 \\
(0.291)\end{array}$ & $\begin{array}{l}-0.432^{10} \\
(0.231)\end{array}$ & $\begin{array}{c}-0.166 \\
(0.144)\end{array}$ \\
\hline Portfolio Co. & $\begin{array}{r}-0.080 \\
(1.041)\end{array}$ & $\begin{array}{r}-0.064 \\
(0.323)\end{array}$ & $\begin{array}{r}0.254 \\
(0.546)\end{array}$ & $\begin{array}{r}0.145 \\
(0.182)\end{array}$ \\
\hline Base & $\begin{array}{r}-0.401 \\
(0.591) \\
\end{array}$ & $\begin{array}{r}-0.086 \\
(0.127) \\
\end{array}$ & $\begin{array}{c}0.346^{\mathbf{5}} \\
(0.136) \\
\end{array}$ & $\begin{array}{c}-0.071 \\
(0.080) \\
\end{array}$ \\
\hline \multicolumn{5}{|c|}{ Foreign Ownership } \\
\hline Industrial Co. & $\begin{array}{r}-0.712 \\
(0.790)\end{array}$ & $\begin{array}{r}-0.234 \\
(0.232)\end{array}$ & $\begin{array}{l}-0.447^{\mathbf{5}} \\
(0.190)\end{array}$ & $\begin{array}{c}-0.143 \\
(0.207)\end{array}$ \\
\hline Others & $\begin{array}{r}-1.347 \\
(1.196)\end{array}$ & $\begin{array}{r}0.650 \\
(0.505)\end{array}$ & $\begin{array}{l}-0.844^{\mathbf{5}} \\
(0.371)\end{array}$ & $\begin{array}{r}0.156 \\
(0.208)\end{array}$ \\
\hline
\end{tabular}


Table 6 (continued)

\begin{tabular}{|c|c|c|c|c|}
\hline & $\begin{array}{l}\text { Operating } \\
\text { Profit }\end{array}$ & Sales & $\begin{array}{l}\text { Labor } \\
\text { Cost }\end{array}$ & $\begin{array}{l}\text { Liability/ } \\
\text { Equity }\end{array}$ \\
\hline \multicolumn{5}{|c|}{$\begin{array}{l}\text { Time Square } \\
\text { Domestic Ownership }\end{array}$} \\
\hline Industrial Co. & $\begin{array}{c}-0.078 \\
(0.187)\end{array}$ & $\begin{array}{r}-0.029 \\
(0.044)\end{array}$ & $\begin{array}{r}0.061 \\
(0.040)\end{array}$ & $\begin{array}{r}-0.010 \\
(0.028)\end{array}$ \\
\hline Bank & $\begin{array}{r}-0.264 \\
(0.233)\end{array}$ & $\begin{array}{r}-0.382 \\
(0.284)\end{array}$ & $\begin{array}{r}0.054 \\
(0.123)\end{array}$ & $\begin{array}{r}-0.011 \\
(0.067)\end{array}$ \\
\hline Invest. Fund & $\begin{array}{r}-0.125 \\
(0.203)\end{array}$ & $\begin{array}{r}-0.046 \\
(0.052)\end{array}$ & $\begin{array}{r}0.072 \\
(0.046)\end{array}$ & $\begin{array}{r}-0.042 \\
(0.032)\end{array}$ \\
\hline Individual & $\begin{array}{l}-0.226 \\
(0.217)\end{array}$ & $\begin{array}{l}-0.144^{10} \\
(0.080)\end{array}$ & $\begin{array}{r}0.128^{5} \\
(0.060)\end{array}$ & $\begin{array}{r}0.038 \\
(0.040)\end{array}$ \\
\hline Portfolio Co. & $\begin{array}{r}0.030 \\
(0.293)\end{array}$ & $\begin{array}{r}0.005 \\
(0.081)\end{array}$ & $\begin{array}{r}-0.026 \\
(0.144)\end{array}$ & $\begin{array}{r}-0.032 \\
(0.045)\end{array}$ \\
\hline Base & $\begin{array}{r}0.070 \\
(0.174)\end{array}$ & $\begin{array}{r}0.003 \\
(0.034)\end{array}$ & $\begin{array}{l}-0.109^{1} \\
(0.035)\end{array}$ & $\begin{array}{r}0.016 \\
(0.024)\end{array}$ \\
\hline \multicolumn{5}{|l|}{ Foreign Ownership } \\
\hline Industrial Co. & $\begin{array}{r}0.183 \\
(0.218)\end{array}$ & $\begin{array}{r}0.055 \\
(0.060)\end{array}$ & $\begin{array}{c}0.118^{\mathbf{5}} \\
(0.048)\end{array}$ & $\begin{array}{r}0.037 \\
(0.051)\end{array}$ \\
\hline Others & $\begin{array}{r}0.313 \\
(0.315) \\
\end{array}$ & $\begin{array}{r}-0.154 \\
(0.126) \\
\end{array}$ & $\begin{array}{r}0.229^{5} \\
(0.101)^{2} \\
\end{array}$ & $\begin{array}{r}-0.044 \\
(0.056) \\
\end{array}$ \\
\hline Initial value & $\begin{array}{c}-1.9 \mathrm{E}-08 \\
(2.1 \mathrm{E}-08) \\
\end{array}$ & $\begin{array}{r}1.4 \mathrm{E}-09 \\
(1.7 \mathrm{E}-09) \\
\end{array}$ & $\begin{array}{r}1.5 \mathrm{E}-08^{10} \\
(7.9 \mathrm{E}-09)\end{array}$ & $\begin{array}{l}-1.9 \mathrm{E}-02 \\
(7.2 \mathrm{E}-03) \\
\end{array}$ \\
\hline \multicolumn{5}{|c|}{ Voucher-Privatization Dummies } \\
\hline First Wave & $\begin{array}{r}0.106 \\
(0.123)\end{array}$ & $\begin{array}{r}0.024 \\
(0.066)\end{array}$ & $\begin{array}{r}-0.078 \\
(0.053)\end{array}$ & $\begin{array}{r}0.185^{1} \\
(0.033)\end{array}$ \\
\hline Second Wave & $\begin{array}{r}0.057 \\
(0.126)\end{array}$ & $\begin{array}{r}0.044 \\
(0.066)\end{array}$ & $\begin{array}{l}-0.099^{10} \\
(0.053)\end{array}$ & $\begin{array}{r}0.134^{1} \\
(0.032)\end{array}$ \\
\hline Both Waves & $\begin{array}{r}0.114 \\
(0.135) \\
\end{array}$ & $\begin{array}{r}0.054 \\
(0.069) \\
\end{array}$ & $\begin{array}{r}-0.069 \\
(0.056) \\
\end{array}$ & $\begin{array}{r}0.173^{1} \\
(0.037)\end{array}$ \\
\hline Inverse of Mills' Ratio & $\begin{array}{r}0.597^{1} \\
(0.151)\end{array}$ & $\begin{array}{l}-0.030^{5} \\
(0.014)\end{array}$ & $\begin{array}{r}-0.006 \\
(0.008)\end{array}$ & $\begin{array}{r}0.408^{1} \\
(0.018)\end{array}$ \\
\hline
\end{tabular}

Note: Numbers in parenthesis are heteroscedasticity consistent standard errors. 1, 5 and 10 denote significance at $1 \%, 5 \%$ and $10 \%$ level, two-tail test, respectively. Industry, year, and privatization dummies included. SLO stands for the single largest owner. All estimates are adjusted for potential sample selection bias using the Heckman (1979) procedure. 
Table 7

Effects of SLO Having Majority or Minority Share Ownership

\begin{tabular}{|c|c|c|c|c|}
\hline & $\begin{array}{c}\text { Operating } \\
\text { Profit }\end{array}$ & Sales & $\begin{array}{l}\text { Labor } \\
\text { Cost }\end{array}$ & $\begin{array}{l}\text { Liability/ } \\
\text { Equity }\end{array}$ \\
\hline Constant (State) & $\begin{array}{r}-0.198 \\
(0.217) \\
\end{array}$ & $\begin{array}{r}0.125 \\
(0.095) \\
\end{array}$ & $\begin{array}{r}0.164^{\mathbf{5}} \\
(0.065) \\
\end{array}$ & $\begin{array}{l}-0.127^{\mathbf{5}} \\
(0.054)\end{array}$ \\
\hline \multicolumn{5}{|l|}{ Owner Type } \\
\hline \multicolumn{5}{|c|}{ Domestic Ownership } \\
\hline Industrial Co. & $\begin{array}{r}0.081 \\
(0.280)\end{array}$ & $\begin{array}{r}-0.038 \\
(0.157)\end{array}$ & $\begin{array}{r}0.051 \\
(0.122)\end{array}$ & $\begin{array}{r}-0.038 \\
(0.073)\end{array}$ \\
\hline Bank & $\begin{array}{r}-0.153 \\
(0.323)\end{array}$ & $\begin{array}{r}1.192 \\
(1.104)\end{array}$ & $\begin{array}{r}-0.152 \\
(0.106)\end{array}$ & $\begin{array}{r}-0.054 \\
(0.085)\end{array}$ \\
\hline Invest. Fund & $\begin{array}{r}0.038 \\
(0.296)\end{array}$ & $\begin{array}{r}-0.075 \\
(0.256)\end{array}$ & $\begin{array}{c}-0.077 \\
(0.112)\end{array}$ & $\begin{array}{l}-0.113^{10} \\
(0.066)\end{array}$ \\
\hline Individual & $\begin{array}{r}0.463 \\
(0.483)\end{array}$ & $\begin{array}{r}0.691 \\
(0.583)\end{array}$ & $\begin{array}{r}-0.001 \\
(0.095)\end{array}$ & $\begin{array}{r}-0.027 \\
(0.060)\end{array}$ \\
\hline Portfolio Co. & $\begin{array}{r}-0.059 \\
(0.287) \\
\end{array}$ & $\begin{array}{r}-0.030 \\
(0.068) \\
\end{array}$ & $\begin{array}{r}0.372 \\
(0.326) \\
\end{array}$ & $\begin{array}{r}-0.122 \\
(0.075) \\
\end{array}$ \\
\hline \multicolumn{5}{|c|}{ Foreign Ownership } \\
\hline Industrial Co. & $\begin{array}{l}-0.211 \\
(0.353)\end{array}$ & $\begin{array}{r}-0.010 \\
(0.081)\end{array}$ & $\begin{array}{l}-0.097^{10} \\
(0.058)\end{array}$ & $\begin{array}{r}0.003 \\
(0.112)\end{array}$ \\
\hline Others & $\begin{array}{r}-0.168 \\
(0.271) \\
\end{array}$ & $\begin{array}{r}-0.048 \\
(0.081) \\
\end{array}$ & $\begin{array}{r}0.170 \\
(0.136) \\
\end{array}$ & $\begin{array}{c}-0.246^{1} \\
(0.092)\end{array}$ \\
\hline Golden Share & $\begin{array}{r}0.056 \\
(0.093)\end{array}$ & $\begin{array}{r}0.013 \\
(0.024)\end{array}$ & $\begin{array}{c}0.053^{1} \\
(0.019)\end{array}$ & $\begin{array}{r}0.002 \\
(0.017)\end{array}$ \\
\hline \multicolumn{5}{|l|}{$\begin{array}{l}\text { Majority } \\
\text { Domestic Owner }\end{array}$} \\
\hline Industrial Co. & $\begin{array}{r}-0.300 \\
(0.238)\end{array}$ & $\begin{array}{r}-0.128 \\
(0.143)\end{array}$ & $\begin{array}{l}-0.195^{10} \\
(0.116)\end{array}$ & $\begin{array}{r}-0.060 \\
(0.059)\end{array}$ \\
\hline Bank & $\begin{array}{r}0.155 \\
(0.308)\end{array}$ & $\begin{array}{r}-1.187 \\
(1.111)\end{array}$ & $\begin{array}{r}0.111 \\
(0.109)\end{array}$ & $\begin{array}{r}-0.078 \\
(0.075)\end{array}$ \\
\hline Invest. Fund & $\begin{array}{r}-0.346 \\
(0.276)\end{array}$ & $\begin{array}{r}-0.071 \\
(0.252)\end{array}$ & $\begin{array}{l}-0.204^{10} \\
(0.116)\end{array}$ & $\begin{array}{r}-0.010 \\
(0.059)\end{array}$ \\
\hline Individual & $\begin{array}{r}-0.628 \\
(0.470)\end{array}$ & $\begin{array}{r}-0.833 \\
(0.582)\end{array}$ & $\begin{array}{c}-0.091 \\
(0.103)\end{array}$ & $\begin{array}{l}-0.106^{5} \\
(0.048)\end{array}$ \\
\hline Portfolio Co. & $\begin{array}{r}0.063 \\
(0.308)\end{array}$ & $\begin{array}{r}0.188 \\
(0.181)\end{array}$ & $\begin{array}{c}-0.383 \\
(0.346)\end{array}$ & $\begin{array}{r}0.029 \\
(0.065)\end{array}$ \\
\hline State & $\begin{array}{l}-0.519^{1} \\
(0.192)\end{array}$ & $\begin{array}{r}-0.072 \\
(0.083) \\
\end{array}$ & $\begin{array}{l}-0.086^{10} \\
(0.050)\end{array}$ & $\begin{array}{r}-0.042 \\
(0.053) \\
\end{array}$ \\
\hline \multicolumn{5}{|c|}{ Foreign Ownership } \\
\hline Industrial Co. & $\begin{array}{r}-0.031 \\
(0.323)\end{array}$ & $\begin{array}{r}0.006 \\
(0.061)\end{array}$ & $\begin{array}{r}0.069 \\
(0.048)\end{array}$ & $\begin{array}{l}-0.192^{10} \\
(0.111)^{10}\end{array}$ \\
\hline Others & $\begin{array}{r}-0.055 \\
(0.346)\end{array}$ & $\begin{array}{r}-0.022 \\
(0.111)\end{array}$ & $\begin{array}{l}-0.320^{5} \\
(0.150)\end{array}$ & $\begin{array}{r}0.060 \\
(0.087)\end{array}$ \\
\hline
\end{tabular}


Table 7 (continued)

\begin{tabular}{|c|c|c|c|c|}
\hline & $\begin{array}{c}\text { Operating } \\
\text { Profit } \\
\end{array}$ & Sales & $\begin{array}{c}\text { Labor } \\
\text { Cost }\end{array}$ & $\begin{array}{c}\text { Liability/ } \\
\text { Equity }\end{array}$ \\
\hline \multicolumn{5}{|l|}{ Blocking Minority } \\
\hline \multicolumn{5}{|c|}{ Domestic Ownership } \\
\hline Industrial Co. & $\begin{array}{c}-0.308 \\
(0.238)\end{array}$ & $\begin{array}{l}-0.123 \\
(0.144)\end{array}$ & $\begin{array}{l}-0.198^{10} \\
(0.115)\end{array}$ & $\begin{array}{c}-0.039 \\
(0.059)\end{array}$ \\
\hline Bank & $\begin{array}{c}-0.526 \\
(0.327)\end{array}$ & $\begin{array}{c}-1.339 \\
(1.108)\end{array}$ & $\begin{array}{r}0.160 \\
(0.137)\end{array}$ & $\begin{array}{l}-0.184 \\
(0.197)\end{array}$ \\
\hline Invest. Fund & $\begin{array}{c}-0.243 \\
(0.274)\end{array}$ & $\begin{array}{r}-0.064 \\
(0.251)\end{array}$ & $\begin{array}{c}-0.075 \\
(0.107)\end{array}$ & $\begin{array}{r}0.000 \\
(0.056)\end{array}$ \\
\hline Individual & $\begin{array}{r}-0.630 \\
(0.468)\end{array}$ & $\begin{array}{r}-0.845 \\
(0.582)\end{array}$ & $\begin{array}{c}-0.1844^{5} \\
(0.089)\end{array}$ & $\begin{array}{c}-0.058 \\
(0.047)\end{array}$ \\
\hline Portfolio Co. & $\begin{array}{l}-0.618^{10} \\
(0.327)\end{array}$ & $\begin{array}{l}-0.180^{1} \\
(0.052)\end{array}$ & $\begin{array}{r}-0.462 \\
(0.333)\end{array}$ & $\begin{array}{r}0.046 \\
(0.074)\end{array}$ \\
\hline State & $\begin{array}{l}-0.387^{5} \\
(0.180)\end{array}$ & $\begin{array}{r}-0.112 \\
(0.071)\end{array}$ & $\begin{array}{l}-0.08310 \\
(0.046)\end{array}$ & $\begin{array}{l}-0.088^{10} \\
(0.047)\end{array}$ \\
\hline \multicolumn{5}{|c|}{ Foreign Ownership } \\
\hline Industrial Co. & $\begin{array}{r}0.199 \\
(0.343)\end{array}$ & $\begin{array}{r}-0.071 \\
(0.059)\end{array}$ & $\begin{array}{r}0.050 \\
(0.043)\end{array}$ & $\begin{array}{c}-0.134 \\
(0.111)\end{array}$ \\
\hline Others & $\begin{array}{r}-0.306 \\
(0.300) \\
\end{array}$ & $\begin{array}{r}-0.091 \\
(0.124) \\
\end{array}$ & $\begin{array}{c}-0.360 \\
(0.140) \\
\end{array}$ & $\begin{array}{r}0.167^{\mathbf{5}} \\
(0.082) \\
\end{array}$ \\
\hline \multicolumn{5}{|l|}{ Legal Minority } \\
\hline \multicolumn{5}{|c|}{ Domestic Ownership } \\
\hline Industrial Co. & $\begin{array}{c}-0.370 \\
(0.240)\end{array}$ & $\begin{array}{r}-0.091 \\
(0.144)\end{array}$ & $\begin{array}{c}-0.169 \\
(0.116)\end{array}$ & $\begin{array}{c}-0.044 \\
(0.059)\end{array}$ \\
\hline Bank & $\begin{array}{c}-0.364 \\
(0.330)\end{array}$ & $\begin{array}{c}-1.421 \\
(1.105)\end{array}$ & $\begin{array}{r}0.074 \\
(0.133)\end{array}$ & $\begin{array}{l}-0.029 \\
(0.087)\end{array}$ \\
\hline Invest. Fund & $\begin{array}{r}-0.287 \\
(0.255)\end{array}$ & $\begin{array}{r}-0.052 \\
(0.248)\end{array}$ & $\begin{array}{r}-0.064 \\
(0.105)\end{array}$ & $\begin{array}{r}0.036 \\
(0.048)\end{array}$ \\
\hline Individual & $\begin{array}{c}-0.740 \\
(0.462)\end{array}$ & $\begin{array}{r}-0.778 \\
(0.581)\end{array}$ & $\begin{array}{c}-0.071 \\
(0.092)\end{array}$ & $\begin{array}{l}-0.07410 \\
(0.045)\end{array}$ \\
\hline Portfolio Co. & $\begin{array}{l}-0.167 \\
(0.288)\end{array}$ & $\begin{array}{l}-0.213^{1} \\
(0.061)\end{array}$ & $\begin{array}{c}-0.497 \\
(0.330)\end{array}$ & $\begin{array}{r}0.004 \\
(0.079)\end{array}$ \\
\hline State & $-0.408^{5}$ & -0.13110 & -0.070 & -0.074 \\
\hline
\end{tabular}


Table 7 (continued)

\begin{tabular}{ccccc}
\hline \hline & $\begin{array}{c}\text { Operating } \\
\text { Profit }\end{array}$ & Sales & $\begin{array}{c}\text { Labor } \\
\text { Cost }\end{array}$ & $\begin{array}{c}\text { Liability/ } \\
\text { Equity }\end{array}$ \\
\hline Foreign Ownership & & & & \\
Industrial Co. & -0.423 & -0.097 & 0.028 & -0.105 \\
Others & $(0.357)$ & $(0.071)$ & $(0.057)$ & $(0.105)$ \\
& -0.419 & -0.123 & -0.190 & 0.129 \\
Initial value & $(0.295)$ & $(0.090)$ & $(0.164)$ & $(0.096)$ \\
\hline Voucher-Privatization Dummies & $0.0 \mathrm{E}+00$ & $0.0 \mathrm{E}+00$ & $0.0 \mathrm{E}+00$ & $0.0 \mathrm{E}+00^{\mathbf{1}}$ \\
First Wave & 0.129 & 0.033 & -0.073 & $0.182 \mathbf{1}$ \\
& $(0.123)$ & $(0.067)$ & $(0.054)$ & $(0.033)$ \\
Second Wave & 0.068 & 0.051 & -0.095 & $0.134 \mathbf{1 0}$ \\
& $(0.126)$ & $(0.067)$ & $(0.054)$ & $(0.032)$ \\
Both Waves & 0.131 & 0.062 & -0.070 & $0.168 \mathbf{1}$ \\
& $(0.135)$ & $(0.069)$ & $(0.057)$ & $(0.036)$ \\
\hline Inverse of Mills' Ratio & 0.612 & -0.033 & -0.006 & $0.409 \mathbf{1}$ \\
& $(0.137)$ & $(0.014)$ & $(0.007)$ & $(0.018)$ \\
\hline \hline
\end{tabular}

Note: Numbers in parenthesis are heteroscedasticity consistent standard errors. 1, 5 and 10 denote significance at $1 \%, 5 \%$ and $10 \%$ level, two-tail test, respectively. Industry, year, and privatization dummies included. SLO stands for the single largest owner. All estimates are adjusted for potential sample selection bias using the Heckman (1979) procedure. 


\section{DAVIDSON INSTITUTE WORKING PAPER SERIES - Most Recent Papers}

The entire Working Paper Series may be downloaded free of charge at: www.wdi.bus.umich.edu

CURRENT AS 5/29/02

\begin{tabular}{|c|c|c|}
\hline Publication & Authors & Date \\
\hline $\begin{array}{l}\text { No. 471: The Effects of Ownership Forms and Concentration on Firm } \\
\text { Performance after Large-Scale Privatization }\end{array}$ & Evzen Kocenda and Jan Svejnar & May 2002 \\
\hline $\begin{array}{l}\text { No. 470: Growth in Transition: What We Know, What We Don't, and } \\
\text { What We Should }\end{array}$ & $\begin{array}{l}\text { Nauro F. Campos and Fabrizio } \\
\text { Coricelli }\end{array}$ & Feb. 2002 \\
\hline $\begin{array}{l}\text { No. 469: Barriers to Investment by Russian Firms: Property Protection } \\
\text { or Credit Constraints? }\end{array}$ & Susan J. Linz & May 2002 \\
\hline No. 468: Job Satisfaction Among Russian Workers & Susan J. Linz & May 2002 \\
\hline $\begin{array}{l}\text { No. 467: Assessing the Problem of Human Capital Mismatch in } \\
\text { Transition Economies }\end{array}$ & $\begin{array}{l}\text { Viliam Druska, Byeong ju Jeong, } \\
\text { Michal Kejak, and Viatcheslav } \\
\text { Vinogradov }\end{array}$ & Mar. 2002 \\
\hline $\begin{array}{l}\text { No. 466: Motivating Russian Workers: Analysis of Age and Gender } \\
\text { Differences }\end{array}$ & Susan J. Linz & Feb. 2002 \\
\hline No. 465: Virtual Reality: Barter and Restructuring in Russian Industry & Gary Krueger and Susan J. Linz & Apr. 2001 \\
\hline $\begin{array}{l}\text { No. 464: Lending of Last Resort, Moral Hazard and Twin Crises: } \\
\text { Lessons from the Bulgarian Financial Crisis 1996/1997 }\end{array}$ & $\begin{array}{l}\text { Michael Berlemann, Kalin } \\
\text { Hristov and Nikolay Nenovsky }\end{array}$ & May 2002 \\
\hline $\begin{array}{l}\text { No. 463: Deindustrialisation. Lessons from the Structural Outcomes of } \\
\text { Post-Communist Transition }\end{array}$ & $\begin{array}{l}\text { Tomasz Mickiewicz and Anna } \\
\text { Zalewska }\end{array}$ & Jan. 2002 \\
\hline $\begin{array}{l}\text { No. 462: Joint Liability Lending and the Rise and Fall of China's } \\
\text { Township and Village Enterprises }\end{array}$ & Albert Park and Minggao Shen & July 2001 \\
\hline $\begin{array}{l}\text { No. 461: A Refinancing Model of Decentralization with Empirical } \\
\text { Evidence from China }\end{array}$ & Albert Park and Minggao Shen & Apr. 2002 \\
\hline $\begin{array}{l}\text { No. 460: The Effects of Market Liberalization on the Relative Earnings } \\
\text { of Chinese Women }\end{array}$ & $\begin{array}{l}\text { Margaret Maurer-Fazio and } \\
\text { James Hughes }\end{array}$ & Mar. 2002 \\
\hline $\begin{array}{l}\text { No. 459: The Role of Education in Determining Labor Market } \\
\text { Outcomes in Urban China's Transitional Labor Markets }\end{array}$ & Margaret Maurer-Fazio & Apr. 2002 \\
\hline $\begin{array}{l}\text { No. 458: Real and Monetary Convergence within the European Union } \\
\text { and Between the European Union and Candidate Countries: } \\
\text { A Rolling Cointegration Approach }\end{array}$ & $\begin{array}{l}\text { Josef C. Brada, Ali M. Kutan and } \\
\text { Su Zhou }\end{array}$ & Apr. 2002 \\
\hline No. 457: Credit Ratings as Coordination Mechanisms & $\begin{array}{l}\text { Arnoud W. A. Boot and Todd T. } \\
\text { Milbourn }\end{array}$ & Mar. 2002 \\
\hline $\begin{array}{l}\text { No. 456: Balkan and Mediterranean Candidates for European Union } \\
\text { Membership: The Convergence of their Monetary Policy with that of the } \\
\text { European Central Bank }\end{array}$ & Josef C. Brada and Ali M. Kutan & Apr. 2002 \\
\hline $\begin{array}{l}\text { No. 455: Russian Financial Transition: The Development of Institutions } \\
\text { and Markets for Growth }\end{array}$ & David M. Kemme & Oct. 2001 \\
\hline $\begin{array}{l}\text { No. 454: Does the Market Pay Off? Earnings Inequality and Returns to } \\
\text { Education in Urban China }\end{array}$ & Xiaogang $\mathrm{Wu}$ and $\mathrm{Yu} \mathrm{Xie}$ & Apr. 2002 \\
\hline $\begin{array}{l}\text { No. 453: Entrepreneurs' Access to Private Equity in China: } \\
\text { The Role of Social Capital }\end{array}$ & Bat Batjargal and Mannie M. Liu & Apr. 2002 \\
\hline $\begin{array}{l}\text { No. 452: The Determinants of Privatised Enterprise Performance in } \\
\text { Russia }\end{array}$ & $\begin{array}{l}\text { Alan A. Bevan, Saul Estrin, Boris } \\
\text { Kuznetsov, Mark E. Schaffer, } \\
\text { Manuela Angelucci, Julian } \\
\text { Fennema and Giovanni } \\
\text { Mangiarotti }\end{array}$ & June 2001 \\
\hline $\begin{array}{l}\text { No. 451: Determinants of Financial Distress: What Drives Bankruptcy } \\
\text { in a Transition Economy? The Czech Republic Case }\end{array}$ & Lubomír Lízal & Jan. 2002 \\
\hline No. 450: Corporate Governance and the Global Social Void & Lee A. Tavis & Oct. 2001 \\
\hline $\begin{array}{l}\text { No. 449: Financial Architecture and Economic Performance: } \\
\text { International Evidence }\end{array}$ & Solomon Tadesse & Aug. 2001 \\
\hline $\begin{array}{l}\text { No. 448: Growth Slowdown Under Central Planning: A Model of Poor } \\
\text { Incentives }\end{array}$ & Zuzana Brixiová and Aleš Bulír & Mar. 2002 \\
\hline
\end{tabular}

